\title{
A Case Study of Mass Transport during the East-West Oscillation of the Asian Summer Monsoon Anticyclone
}

\author{
Jiali Luo, Jiayao Song, Hongying Tian, Lei Liu, and Xinlei Liang \\ Key Laboratory for Semi-Arid Climate Change of the Ministry of Education, College of Atmospheric Sciences, \\ Lanzhou University, Lanzhou, China \\ Correspondence should be addressed to Jiali Luo; luojl@lzu.edu.cn
}

Received 26 May 2017; Revised 16 August 2017; Accepted 27 August 2017; Published 10 October 2017

Academic Editor: Yu Liu

Copyright (C) 2017 Jiali Luo et al. This is an open access article distributed under the Creative Commons Attribution License, which permits unrestricted use, distribution, and reproduction in any medium, provided the original work is properly cited.

We use ERA-Interim reanalysis, MLS observations, and a trajectory model to examine the chemical transport and tracers distribution in the Upper Troposphere and Lower Stratosphere (UTLS) associated with an east-west oscillation case of the anticyclone in 2016. The results show that the spatial distribution of water vapor $\left(\mathrm{H}_{2} \mathrm{O}\right)$ was more consistent with the location of the anticyclone than carbon monoxide $(\mathrm{CO})$ at $100 \mathrm{hPa}$, and an independent relative high concentration center was only found in $\mathrm{H}_{2} \mathrm{O}$ field. At $215 \mathrm{hPa}$, although the anticyclone center also migrated from the Tibetan Mode (TM) to the Iranian Mode (IM), the relative high concentration centers of both tracers were always colocated with regions where upward motion was strong in the UTLS. When the anticyclone migrated from the TM, air within the anticyclone over Tibetan Plateau may transport both westward and eastward but was always within the UTLS. The relative high concentration of tropospheric tracers within the anticyclone in the IM was from the east and transported by the westward propagation of the anticyclone rather than being lifted from surface directly. Air within the relative high geopotential height centers over Western Pacific was partly from the main anticyclone and partly from lower levels.

\section{Introduction}

The Asian summer monsoon is an important component of global climate system and also a significant system of global atmospheric circulation in boreal summer [1]. Given its impact on northern hemispheric weather and climate and its role in ocean-atmosphere interaction and StratosphereTroposphere Exchange (STE), studies focusing on the Asian summer monsoon have been widely investigated [2-15]. STE has a significant effect on transport across tropopause and spatial distribution of atmospheric component [16, 17]. The Asian summer monsoon anticyclone (South Asia High) is one of the dominant features of the Asian summer monsoon $[1,18-26]$. It plays an important role in STE because of persistent deep convections and the impact on mass transport, especially on chemical distribution in the Upper Troposphere and Lower Stratosphere (UTLS) region [9, 19, 20, 27-29]. The Asian summer monsoon anticyclone is bounded by the westerly jet to the north and easterly jet to the south which leads to independent feature of air inside of the anticyclone
$[23,24]$. Surface pollution in Asia can be transported to stratosphere via the anticyclone $[30,31]$. Previous studies have shown that there exists seasonal mean maximum (or minimum) of tropospheric tracers such as carbon monoxide $(\mathrm{CO}), \mathrm{HCN}$, and water vapor $\left(\mathrm{H}_{2} \mathrm{O}\right)$ (of stratospheric tracers such as $\mathrm{O}_{3}$ ) in the UTLS region during the Asian summer monsoon season [20, 23, 30-34].

Although the Asian summer monsoon anticyclone is a very strong and steady circulation in the UTLS region, it also shows westward migration from Tibetan Plateau (TP) [35] and the anticyclone breaks off (every 10-20 days) several times, when it migrates westward [36] (we call it 10-20-day east-west oscillation in this study). Randel and Park [1] have shown that the monsoon circulation has active/break cycles, which is linked to the oscillation of deep convection with a timescale of 10-20 days. Zhang et al. [37] found that South Asia High (SAH) shows bimodality in the longitude location and is classified to Tibetan mode (centered at about $90^{\circ} \mathrm{E}$ ) and Iranian mode (centered at about $60^{\circ} \mathrm{E}$ ). The distribution of chemical constituents in the UTLS region is influenced by 
the bimodality $[38,39]$. However, the STE variability during the east-west oscillation of the Asian summer monsoon anticyclone is still unknown. It is important to diagnose the air transport associated with the east-west oscillation of the anticyclone.

There are also studies focused on the air transport details during the Asian summer monsoon season. Bergman et al. [40] pointed out that the lifted air caused by convections may go downward to lower troposphere again during monsoon season. The trajectory and WRF-Chem model output shows that tropospheric air which can be transported directly to stratosphere is mainly from TP. The orographic lifting of TP rather than convective transport contributes to the upward transport [41]. Garny and Randel [42] further indicated that air above $360 \mathrm{~K}$ isentropic surface is more likely to be confined inside of the anticyclone, while air below is difficult to access stratosphere. The relative importance of tropospheric upward lifting and confinement of the anticyclone in STE during the anticyclone oscillation needs to be studied.

The goal of this work is to diagnose the mass transport when the Asian summer monsoon anticyclone oscillates from Tibetan mode to Iranian mode. Chemical species mixing ratio from satellite data, meteorological field from reanalysis data, and a trajectory model are combined to address the following questions: (1) How does the east-west oscillation of the Asian summer monsoon anticyclone influence chemical distribution in the UTLS? (2) Is the air within the anticyclone in different phases has the same sources? (3) How does air within the anticyclone transport when the anticyclone migrates from Tibetan mode to Iranian mode?

We choose $\mathrm{CO}$ and $\mathrm{H}_{2} \mathrm{O}$ as tropospheric tracers for transport diagnosis. $\mathrm{CO}$ is a good tracer of transport in the troposphere and lower stratosphere [43], since it has a photochemical lifetime of 2-3 months [44]. Relatively high $\mathrm{H}_{2} \mathrm{O}$ mixing ratio in upper troposphere and near tropopause has been observed within the Asian summer monsoon anticyclone $[23,45]$. Here we analyze space-time variability of $\mathrm{CO}$ and $\mathrm{H}_{2} \mathrm{O}$ in the UTLS to investigate the mass transport that is related to the anticyclone oscillation.

\section{Data and Model}

2.1. Satellite Data. The Microwave Limb Sounder (MLS) instrument is on the NASA EOS Aura satellite mission launched on 15 July 2004 [46]. Here we use MLS Version 4, Level $2 \mathrm{CO}$, and $\mathrm{H}_{2} \mathrm{O}$ data at both $100 \mathrm{hPa}$ and $215 \mathrm{hPa}$. The vertical resolution of CO retrievals at $100 \mathrm{hPa}$ is $4.9 \mathrm{~km}$ and the precision is $\sim 14 \mathrm{ppbv}$ with a systematic uncertainty of $\sim 20$ ppbv. At $215 \mathrm{hPa}$, they are $5.4 \mathrm{~km}, \sim 19 \mathrm{ppbv}$, and $\sim 30 \mathrm{ppbv}$. The $\mathrm{H}_{2} \mathrm{O}$ retrieval has a vertical resolution of $3 \mathrm{~km}$ at $100 \mathrm{hPa}$ and $1.6 \mathrm{~km}$ at $215 \mathrm{hPa}$. The precision and accuracy are $\sim 15 \%$ and $\sim 8 \%$ at $100 \mathrm{hPa}$, as well as $\sim 40 \%$ and $\sim 25 \%$ at $215 \mathrm{hPa}$, respectively [47]. The horizontal resolution of MLS data is $\sim 6 \mathrm{~km}$ across the track and $\sim 300 \mathrm{~km}$ along the track. We construct gridded data on 5 -degree latitude $\times 5$-degree longitude to make the daily maps.

2.2. Meteorology Data. We use 6-hourly geopotential height $(\mathrm{GPH})$, horizontal wind field ( $u$ and $v)$, and vertical velocity
( $\omega)$ from ERA-Interim reanalysis in August 2016 in this work to diagnose the dynamical variability of Asian summer monsoon anticyclone and tropospheric upward motion. The horizontal resolution is $1^{\circ}$ on 37 pressure levels (from $1000 \mathrm{hPa}$ to $1 \mathrm{hPa}$ ).

2.3. Trajectory Model. We use Hybrid Single-Particle Lagrangian Integrated Trajectory (HYSPLIT) model to track both forward and backward trajectories in this study. The HYSPLIT model assumes a three-dimensional particle distribution [48-50]. The mean particle trajectory is the integration of the particle position vector in space and time [51]. It has been widely used in air transport during Asian summer monsoon season $[41,52]$. Given that analysis based on individual trajectories may have uncertainties, we used an ensemble approach to do the analysis. The ensemble approach starts multiple trajectories from a selected starting location. It computes trajectories for 27 starting locations for each specified location. The 27 trajectories are on three vertical levels and there are nine locations for each level. Each trajectory in the approach is calculated by offsetting the meteorological data by a fixed grid factor. The 27 trajectories are used for all possible offsets in three directions [53].

\section{Chemical Distribution in the UTLS Associated with the Oscillation of the Asian Summer Monsoon Anticyclone}

Although the Asian summer monsoon anticyclone is a stationary circulation on seasonal time scale, analysis reveals that it also shows smaller timescales propagation; in particular, 10-20-day east-west oscillation is evident in dynamical fields and model simulated tropospheric tracers $[36,39]$. To examine characteristics of STE when the anticyclone center migrates from Tibetan mode to Iranian mode, we first chose a period during which the center of the anticyclone showed an integrated westward oscillation.

Figure 1 shows a time evolution of the anticyclone at $100 \mathrm{hPa}$ in August 2016. The location and center of the anticyclone are indicated by selected GPH contours. During the time period, the anticyclone showed different phases of the east-west oscillation. It was in the Tibetan mode on Aug 3 (center of the anticyclone located at east of $90^{\circ} \mathrm{E}$ and north of $35^{\circ} \mathrm{N}$ ) and gradually migrated westward (on Aug 7 and Aug 9). There was an independent relative high GPH center appearing to the east of the main anticyclone (centered at about $150^{\circ} \mathrm{E}$ ) on Aug 7. Then the western center continued to migrate further west and the area became smaller, while the eastern one almost maintained. Figure $1(\mathrm{~d})$ indicates that a new Tibetan mode center on Aug 9 appeared and strengthened in the following days (Aug 10 and Aug 14).

The confinement of chemical tracers in the Asian summer monsoon anticyclone occurs around $200-100 \mathrm{hPa}$ or $12-16 \mathrm{~km}$ [1], while the strongest closed circulation of the anticyclone occurs at $\sim 15 \mathrm{~km}$, above the main convective outflow level $(\sim 12 \mathrm{~km})$ [24]. Park et al. [23] have pointed out that upper tropospheric $\mathrm{H}_{2} \mathrm{O}$ in the monsoon region is consistent with deep convection in both location and 


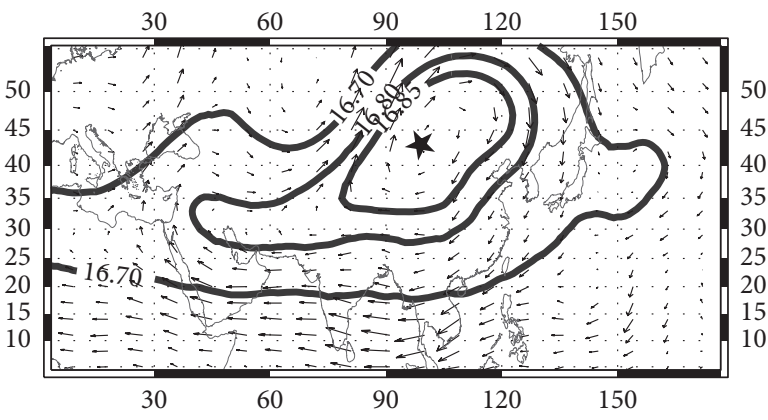

(a) $100 \mathrm{hPa}$ GPH $[\mathrm{km}]$ and wind field $[\mathrm{m} / \mathrm{s}]$ on Aug 3, 2016

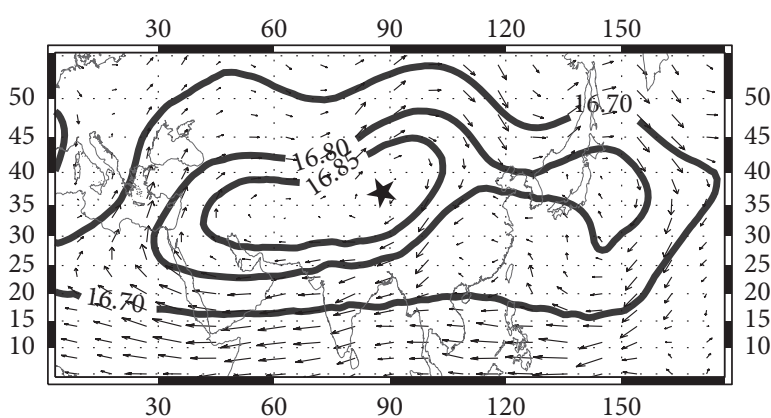

(c) $100 \mathrm{hPa} \mathrm{GPH}[\mathrm{km}]$ and wind field $[\mathrm{m} / \mathrm{s}]$ on Aug 7, 2016

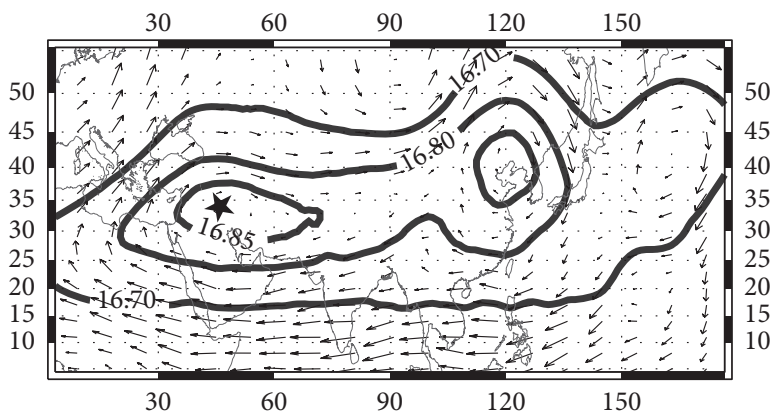

(e) $100 \mathrm{hPa}$ GPH $[\mathrm{km}]$ and wind field $[\mathrm{m} / \mathrm{s}]$ on Aug 10, 2016

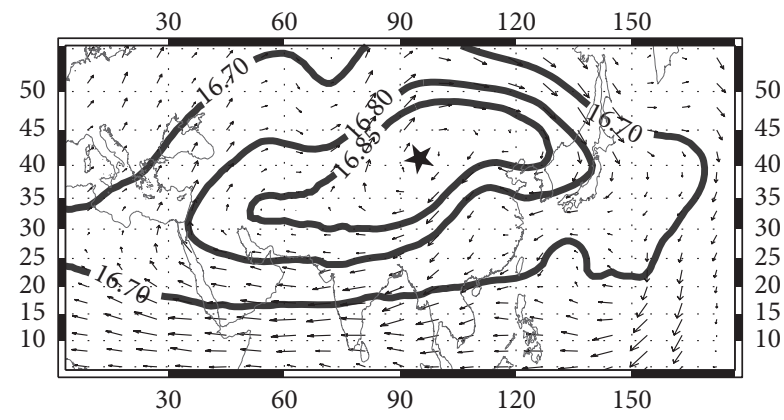

(b) $100 \mathrm{hPa}$ GPH $[\mathrm{km}]$ and wind field $[\mathrm{m} / \mathrm{s}]$ on Aug 5, 2016

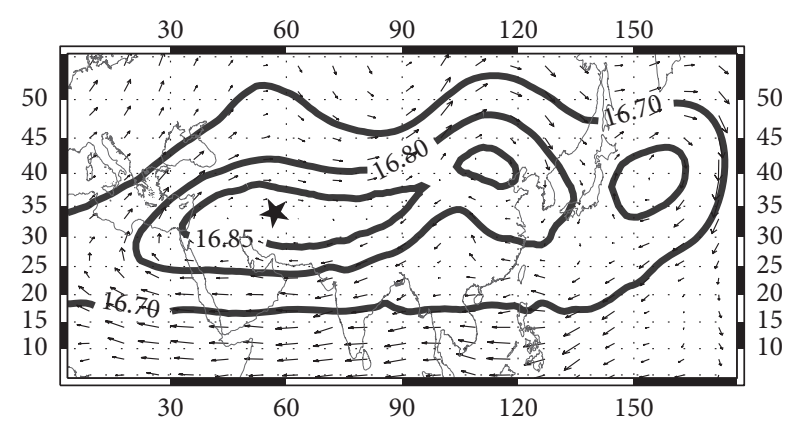

(d) $100 \mathrm{hPa}$ GPH $[\mathrm{km}]$ and wind field $[\mathrm{m} / \mathrm{s}]$ on Aug 9, 2016

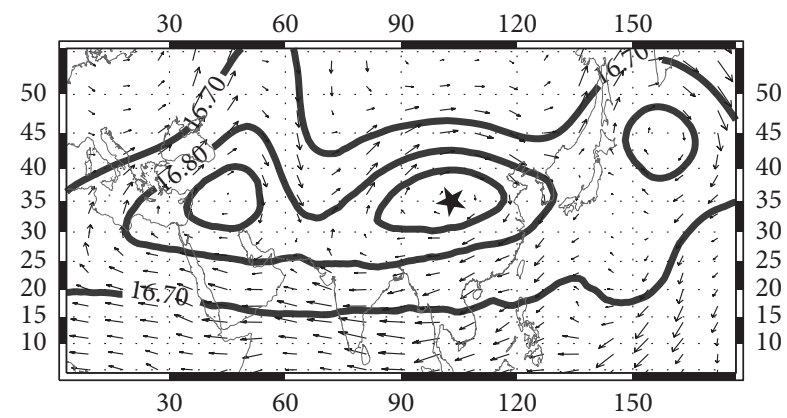

(f) $100 \mathrm{hPa}$ GPH $[\mathrm{km}]$ and wind field $[\mathrm{m} / \mathrm{s}]$ on Aug 14, 2016

Figure 1: Daily maps of geopotential height (GPH, thick contour) and horizontal wind field (vectors) at $100 \mathrm{hPa}$ on (a) Aug 3, (b) Aug 5, (c) Aug 7, (d) Aug 9, (e) Aug 10, and (f) Aug 14, 2016. The GPH contours are $16.70 \mathrm{~km}, 16.80 \mathrm{~km}$, and $16.85 \mathrm{~km}$. The five-pointed star indicates maximum of GPH in the Asian summer monsoon region $\left(10-40^{\circ} \mathrm{N}, 30-150^{\circ} \mathrm{E}\right)$.

evolution. On seasonal scale, the distribution of $\mathrm{H}_{2} \mathrm{O}$ at the altitude of the tropopause is more influenced by the location of the anticyclone. In order to better characterize mass transport associated with the east-west oscillation of the Asian summer monsoon anticyclone, we further looked into the anticyclone variation at $200 \mathrm{hPa}$.

Figure 2 shows the anticyclone evolution at $200 \mathrm{hPa}$ during the same period as in Figure 1. The sequence of the maps demonstrates that although the anticyclone was over TP on Aug 3 (the center of the anticyclone located near $80^{\circ} \mathrm{E}$ ), the main anticyclone located westerly than that at $100 \mathrm{hPa}$ before Aug 10. In addition, an independent relative high GPH center at about $150^{\circ} \mathrm{E}$ also can be found from Aug 7. We call it the eastward eddy shedding of the Asian summer monsoon anticyclone in the following (e.g., [36, 39]).

Although the anticyclone shows disparity between two levels, the evolutions are basically consistent with each other.
As we mentioned above, the chemical distribution in the UTLS is impacted by both anticyclone confinement and deep convections. Horizontal distributions of tropospheric tracers $\left(\mathrm{CO}\right.$ and $\mathrm{H}_{2} \mathrm{O}$ ) and vertical velocity in the UTLS are analyzed to identify which process played more important role in air transport in the UTLS during the period we selected.

Previous studies $[38,39]$ have shown that $\mathrm{CO}$ distribution on smaller time scales in the UTLS is influenced by the anticyclone variability. Relative high CO mixing ratio center is always within the anticyclone. During the same period as in Figures 1 and 2, we found that the regions with relative high CO mixing ratio (yellow and orange regions in Figure 3) from MLS observation at $100 \mathrm{hPa}$ were between 0 and $40^{\circ} \mathrm{N}$, to the west of $120^{\circ} \mathrm{E}$. Specifically speaking, the Iranian mode on Aug 7, Aug 9, and Aug 10 was well shown in MLS CO a little southward, while it was not so clear in Tibetan mode (on Aug 3 and Aug 5) and in the eastward eddy shedding (after Aug 7) 


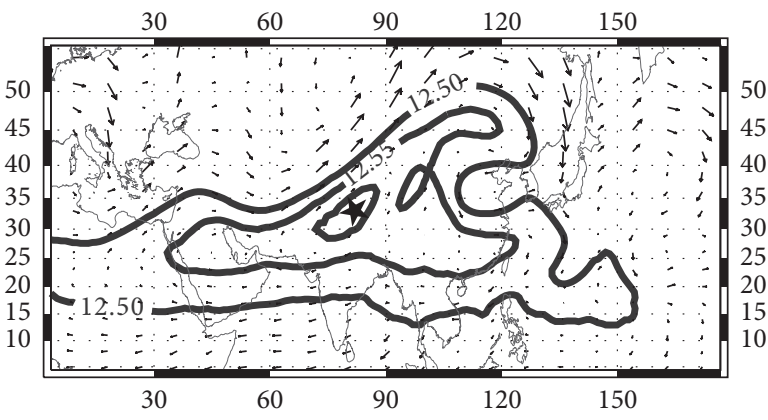

(a) $200 \mathrm{hPa}$ GPH $[\mathrm{km}]$ and wind field $[\mathrm{m} / \mathrm{s}]$ on Aug 3, 2016

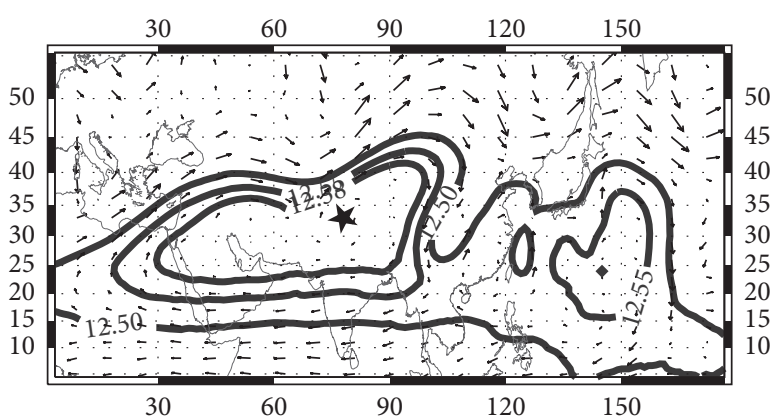

(c) $200 \mathrm{hPa} \mathrm{GPH}[\mathrm{km}]$ and wind field [m/s] on Aug 7, 2016

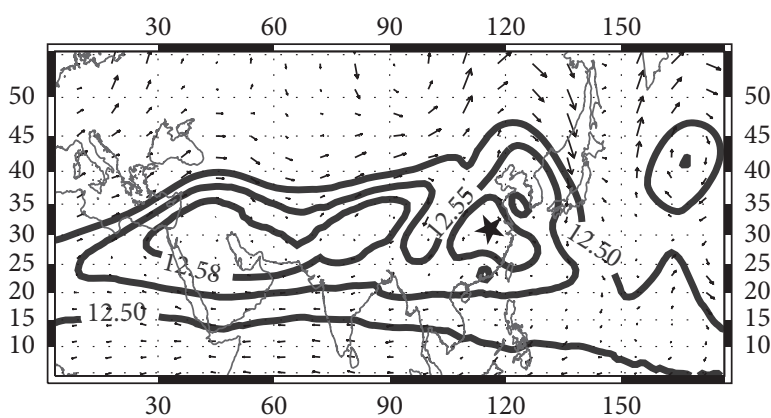

(e) $200 \mathrm{hPa}$ GPH $[\mathrm{km}]$ and wind field $[\mathrm{m} / \mathrm{s}]$ on Aug 10, 2016

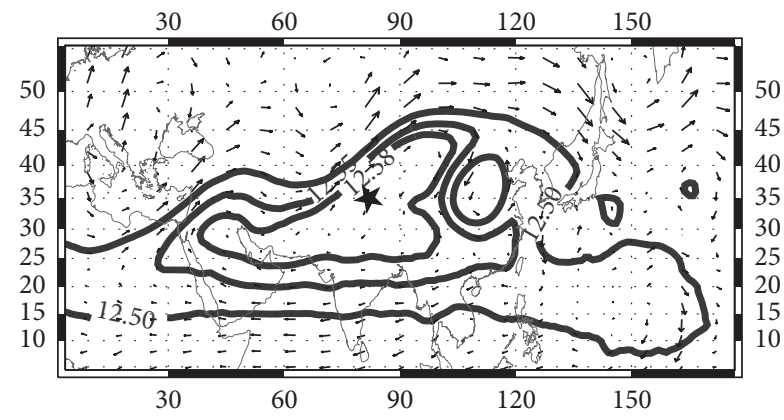

(b) $200 \mathrm{hPa} \mathrm{GPH}[\mathrm{km}]$ and wind field $[\mathrm{m} / \mathrm{s}]$ on Aug 5, 2016

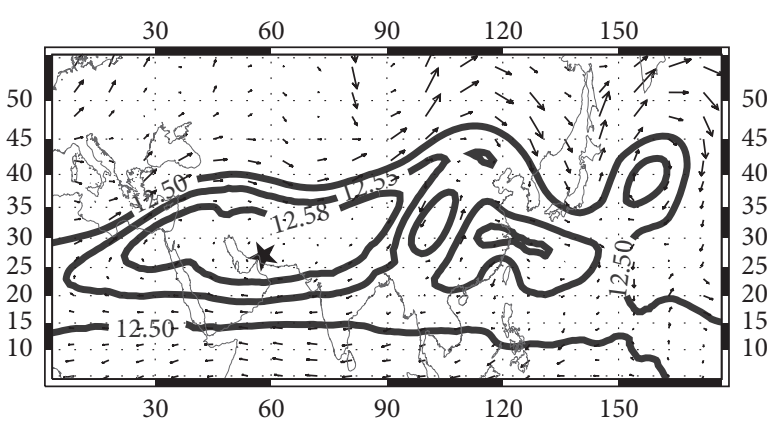

(d) $200 \mathrm{hPa} \mathrm{GPH}[\mathrm{km}]$ and wind field [m/s] on Aug 9, 2016

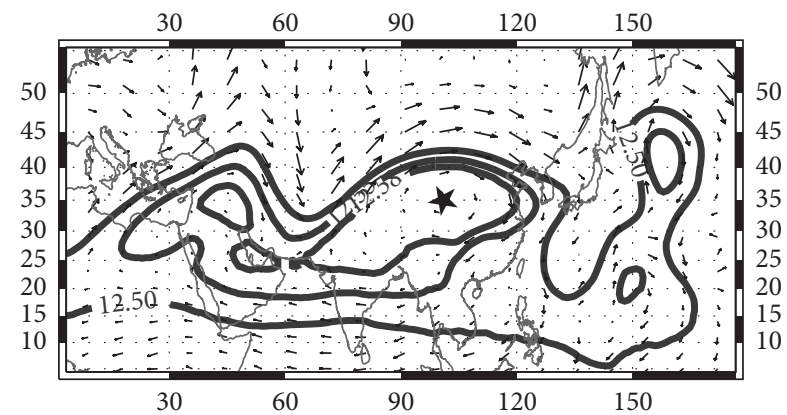

(f) $200 \mathrm{hPa}$ GPH $[\mathrm{km}]$ and wind field $[\mathrm{m} / \mathrm{s}]$ on Aug 14, 2016

Figure 2: The same as Figure 1, but at $200 \mathrm{hPa}$. The GPH contours are $12.50 \mathrm{~km}, 12.55 \mathrm{~km}$, and $12.58 \mathrm{~km}$.

of the anticyclone (Figure 1). Note that the gridded MLS CO has a relative coarser horizontal resolution than ERA-Interim data. We constructed the data onto a regular grid which may induce the location shifting compared to dynamical field and to lose smaller scale features. The horizontal distribution of vertical velocity indicates that upward transport on this level was evident in this sequence. However, regions with strong upward transport did not coincide with maximum $\mathrm{CO}$ mixing ratio centers.

On the other hand, $\mathrm{CO}$ at $215 \mathrm{hPa}$ shows a different evolution from that at $100 \mathrm{hPa}$ (Figure 4). The relative high $\mathrm{CO}$ centers were mainly in the Tibetan mode, that is, located to $60^{\circ} \mathrm{E}$. There were also relative high $\mathrm{CO}$ centers located to the northeast and southwest of the main center. The enhanced CO mixing ratio regions were collocated with strong upward motion but dislocated with the anticyclone center. That indicates that tropospheric upward transport has more influence on $\mathrm{CO}$ distribution than anticyclone confinement at $215 \mathrm{hPa}$.
Relatively high $\mathrm{H}_{2} \mathrm{O}$ mixing ratio near tropopause within Asian summer monsoon anticyclone is also well known $[1,18$, $20,23,54]$. However, it has different features from $\mathrm{CO}$ in the UTLS during the Asian summer monsoon season [23]. We then diagnosed $\mathrm{H}_{2} \mathrm{O}$ horizontal distribution at both $100 \mathrm{hPa}$ and $215 \mathrm{hPa}$ to further understand the relationship between chemical distribution and dynamical processes.

At $100 \mathrm{hPa}, \mathrm{H}_{2} \mathrm{O}$ field shows better relationship with the oscillation of the anticyclone than CO (Figure 5). Relative high $\mathrm{CO}$ centers at $100 \mathrm{hPa}$ located southerly and the Tibetan mode was not shown, while we can see relative high $\mathrm{H}_{2} \mathrm{O}$ regions over TP and IP. Centers of relative high $\mathrm{H}_{2} \mathrm{O}$ and the anticyclone were not exactly colocated, but the longitudinal movements were overall consistent. We have clarified that the disparity of $\mathrm{CO}$ distribution and location of the anticyclone may be caused by the relative coarse horizontal resolution of MLS data. But both $\mathrm{CO}$ and $\mathrm{H}_{2} \mathrm{O}$ variability at $100 \mathrm{hPa}$ during the period indicate that mass distribution on this level migrated from Tibetan mode to Iranian mode with the 


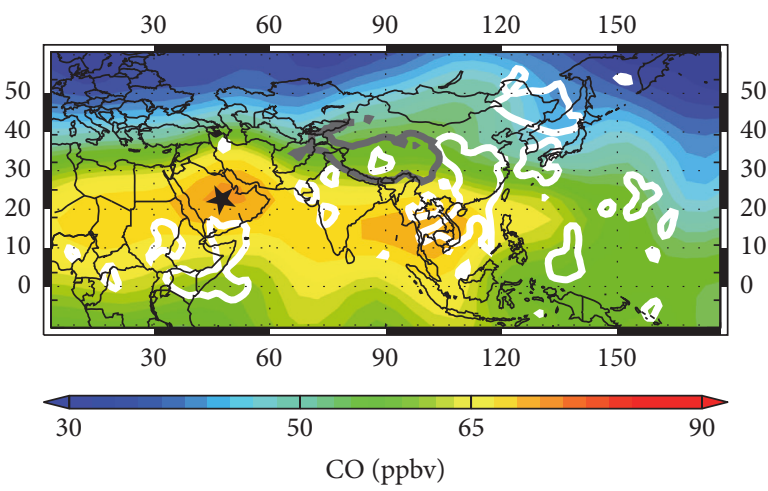

(a) $100 \mathrm{hPa}$ MLS CO [ppbv] on Aug 3, 2016

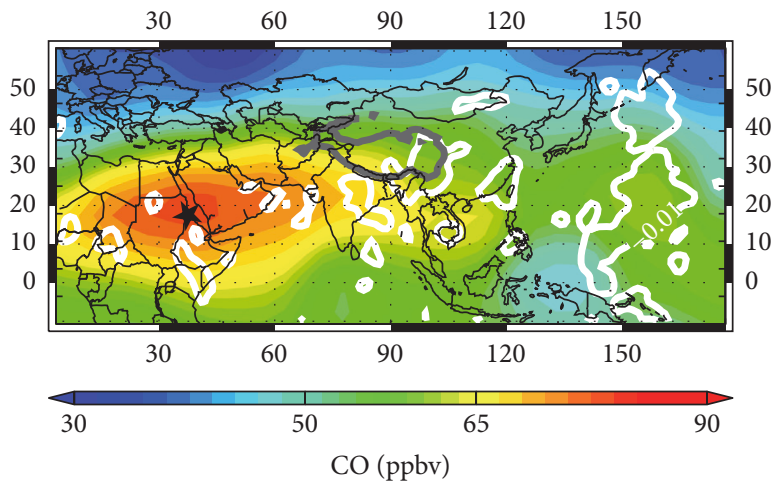

(c) $100 \mathrm{hPa}$ MLS CO [ppbv] on Aug 7, 2016

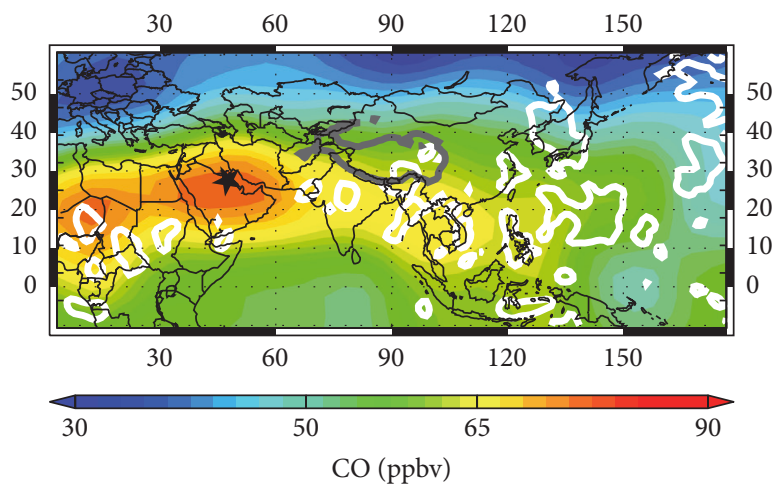

(e) $100 \mathrm{hPa}$ MLS CO [ppbv] on Aug 10, 2016

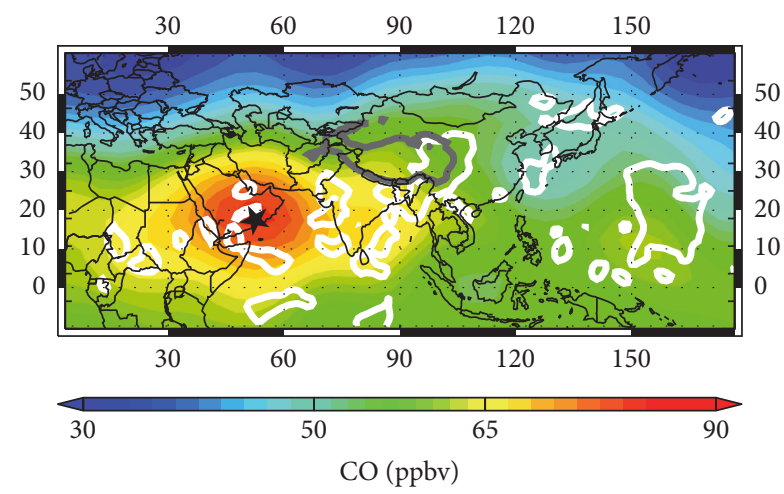

(b) $100 \mathrm{hPa}$ MLS CO [ppbv] on Aug 5, 2016

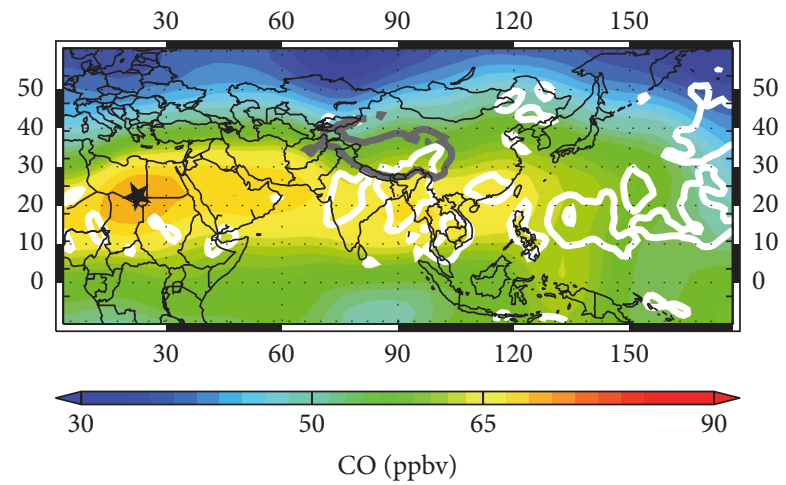

(d) 100 hPa MLS CO [ppbv] on Aug 9, 2016

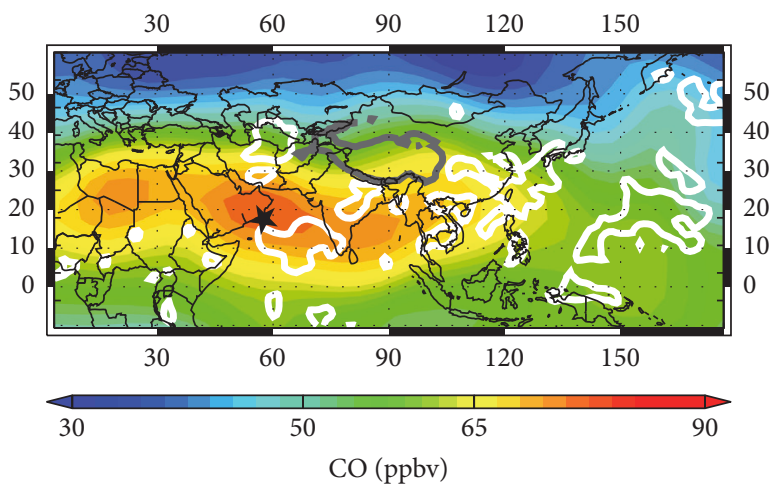

(f) $100 \mathrm{hPa}$ MLS CO [ppbv] on Aug 14, 2016

FIGURE 3: Daily maps of MLS CO mixing ratio at $100 \mathrm{hPa}$ (color shading) on (a) Aug 3, (b) Aug 5, (c) Aug 7, (d) Aug 9, (e) Aug 10, and (f) Aug 14, 2016. The thick gray lines are the $600 \mathrm{hPa}$ contour of surface pressure, indicating the location of the Tibetan Plateau (TP). The regions inside of the white contours represent areas with upward transport (vertical velocity less than $-1 \mathrm{~Pa} / \mathrm{s}$ ) at $100 \mathrm{hPa}$. The five-pointed star indicates maximum of $\mathrm{CO}$ mixing ratio in the Asian summer monsoon region.

anticyclone. In particularly, the eastward eddy shedding is evident in $\mathrm{H}_{2} \mathrm{O}$ distribution.

The $\mathrm{H}_{2} \mathrm{O}$ horizontal structure at $215 \mathrm{hPa}$ shows enhanced mixing ratio near the regions with strong upward movement (Figure 6). The westward oscillation which was evident in dynamical field is not shown in $\mathrm{H}_{2} \mathrm{O}$ sequence at $215 \mathrm{hPa}$ either. This structure is similar to $\mathrm{CO}$ field on this level (Figure 4). Park et al. [23] have pointed that maximum $\mathrm{H}_{2} \mathrm{O}$ mixing ratio at the altitude near tropopause is within the anticyclone, while that in upper troposphere is coherent with deep convections in seasonal scales. The day-to-day behavior of $\mathrm{H}_{2} \mathrm{O}$ further illustrated that chemical distribution in the UTLS was influenced by both the confinement of the anticyclone and deep convections. They show different importance on different levels.

Another feature in chemical distributions in the UTLS is that although $\mathrm{CO}$ at $100 \mathrm{hPa}$ did not show an independent relative high value center to the east of the main anticyclone over Western Pacific, it can be found in $\mathrm{H}_{2} \mathrm{O}$ field on both levels. In addition, we can also found the relative high $\mathrm{CO}$ 


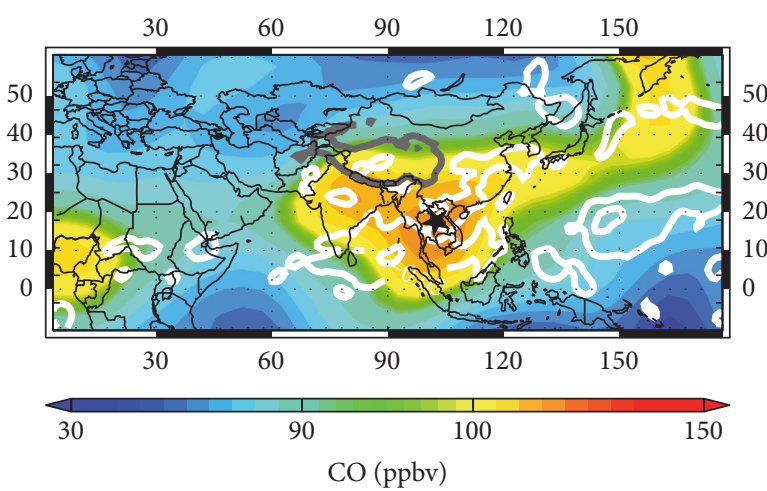

(a) $215 \mathrm{hPa}$ MLS CO [ppbv] on Aug 3, 2016

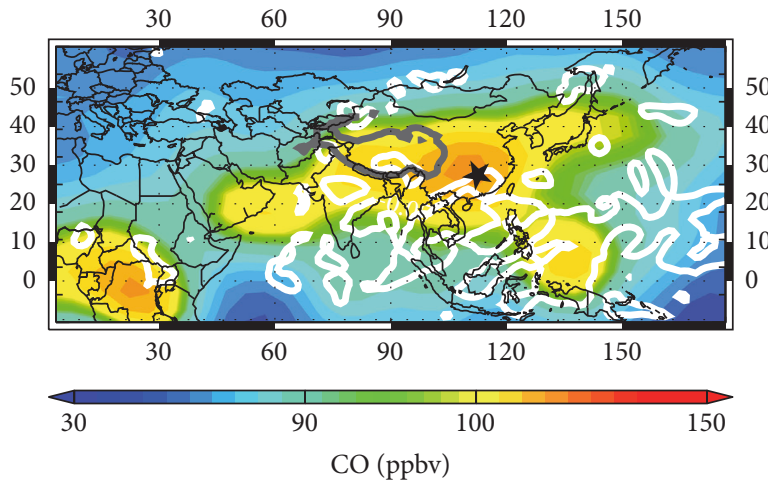

(c) $215 \mathrm{hPa}$ MLS CO [ppbv] on Aug 7, 2016

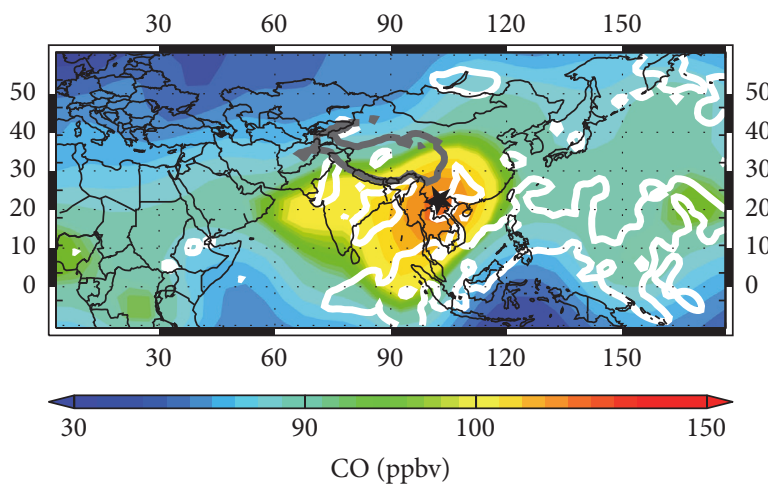

(e) $215 \mathrm{hPa}$ MLS CO [ppbv] on Aug 10, 2016

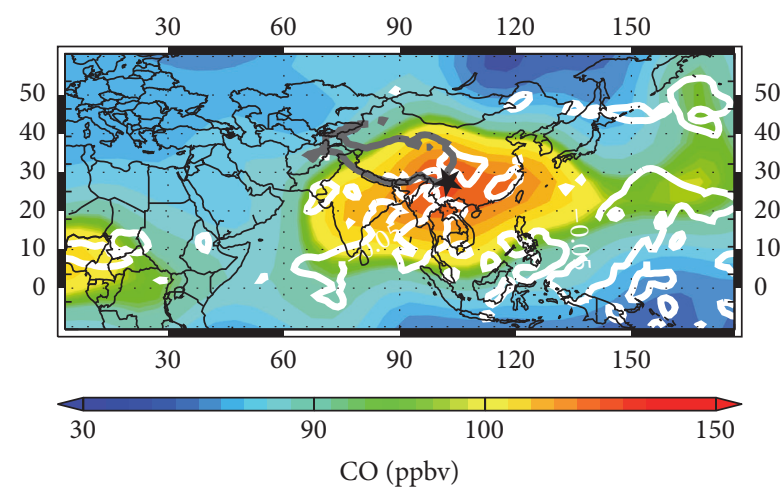

(b) $215 \mathrm{hPa}$ MLS CO [ppbv] on Aug 5, 2016

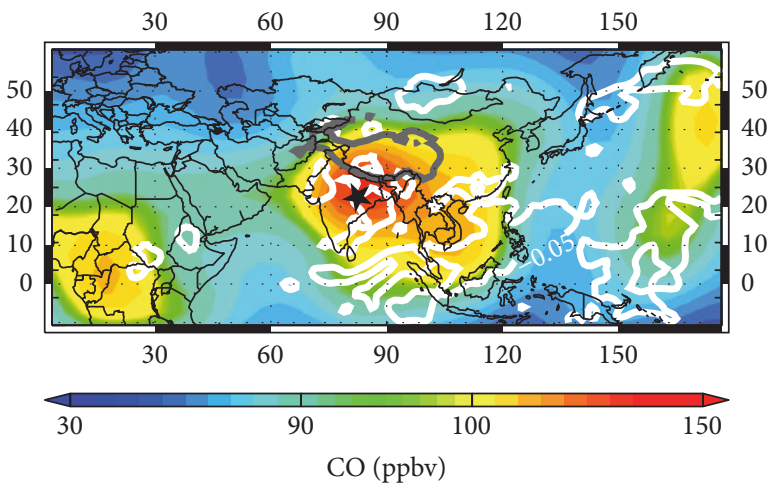

(d) $215 \mathrm{hPa}$ MLS CO [ppbv] on Aug 9, 2016

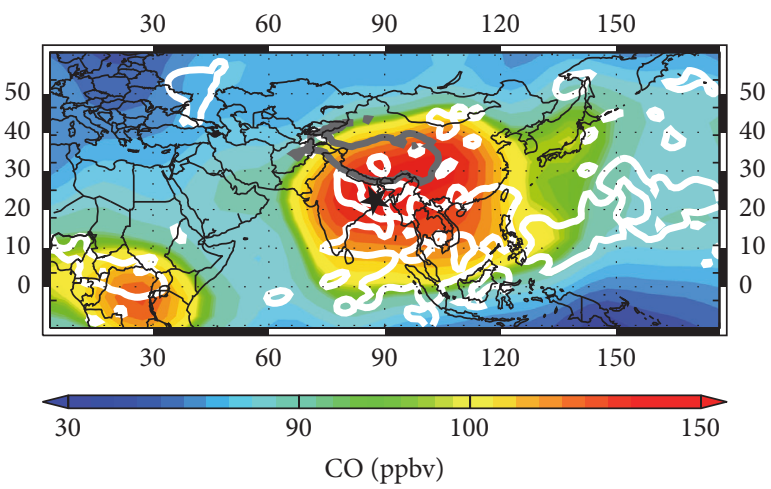

(f) $215 \mathrm{hPa}$ MLS CO [ppbv] on Aug 14, 2016

Figure 4: The same as Figure 3, but for MLS CO at $215 \mathrm{hPa}$ and vertical velocity at $200 \mathrm{hPa}$. The vertical velocity contours are $-5 \mathrm{~Pa} / \mathrm{s}$.

centers to the east of the main anticyclone at $215 \mathrm{hPa}$. The regions with enhanced $\mathrm{H}_{2} \mathrm{O}$ mixing ratio over Western Pacific are larger than those with enhanced $\mathrm{CO}$. Moreover, the regions with enhanced $\mathrm{H}_{2} \mathrm{O}$ mixing ratio were connected to the main anticyclone. The relative high values centers of both tracers to the east of the main anticyclone on lower levels were more evident than on upper levels indicating that the eastern centers over Western Pacific are likely resulting from the upward transport of near-surface air with high $\mathrm{CO}$ and $\mathrm{H}_{2} \mathrm{O}$. The western center of the tracers' maximum at $100 \mathrm{hPa}$ was probably attributed by the anticyclone migration. Based on the uncertainty, we will further measure the vertical transport in troposphere and track the air parcel trajectories.

\section{Tropospheric Upward Motion}

Deep convections associated with the Asian summer monsoon play an important role in surface emissions transporting into the UTLS $[21,31]$. The time-averaged deep convection located in the southeast of the Asian summer monsoon anticyclone (e.g., $[23,31])$. Previous studies have shown that TP is a preferred location for tropospheric tracers to be lifted to upper levels [34-36]. To identify the mass transport in troposphere during the period we chosen, we selected two cross-sections, along $20^{\circ} \mathrm{N}$ (in the south of the Asian summer monsoon anticyclone) and along $30^{\circ} \mathrm{N}$ (over TP), to analyze the vertical transport. 


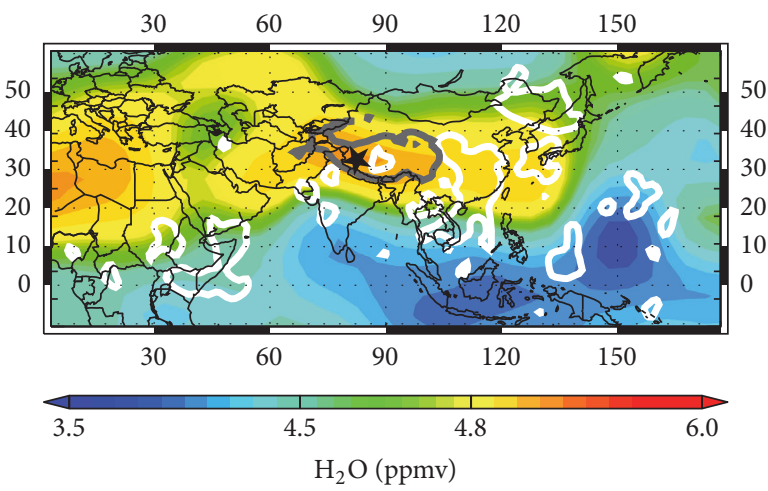

(a) $100 \mathrm{hPa}$ MLS $\mathrm{H}_{2} \mathrm{O}$ [ppmv] on Aug 3, 2016

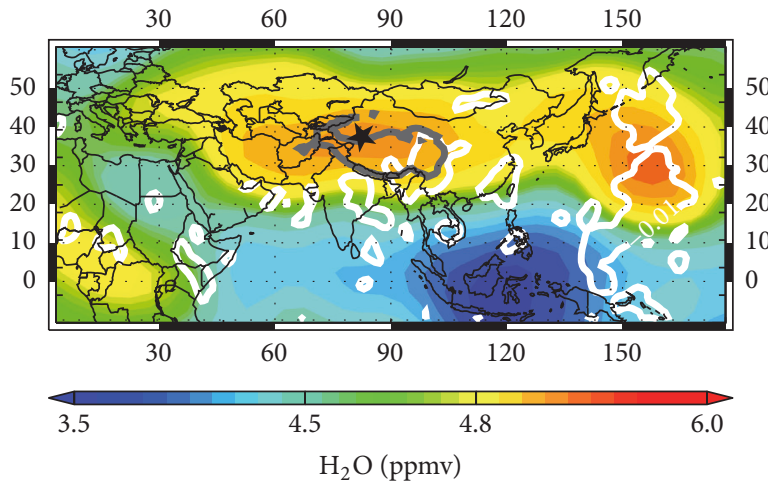

(c) $100 \mathrm{hPa}$ MLS $\mathrm{H}_{2} \mathrm{O}$ [ppmv] on Aug 7, 2016

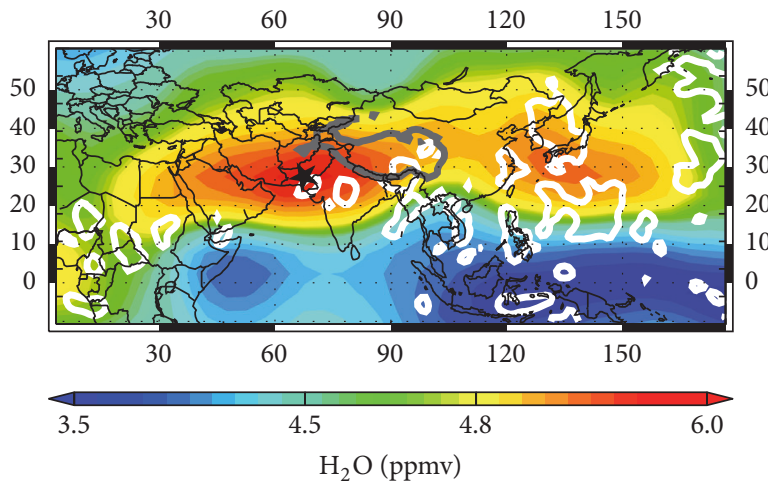

(e) $100 \mathrm{hPa} \mathrm{MLS}_{2} \mathrm{O}$ [ppmv] on Aug 10, 2016

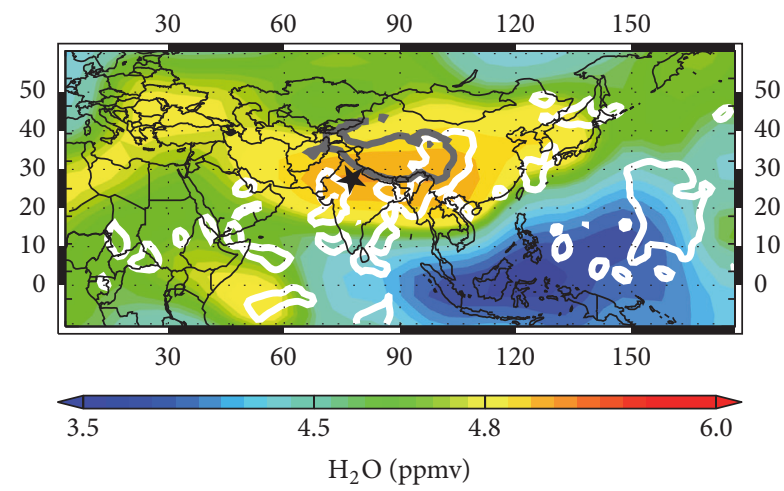

(b) $100 \mathrm{hPa}$ MLS $\mathrm{H}_{2} \mathrm{O}$ [ppmv] on Aug 5, 2016

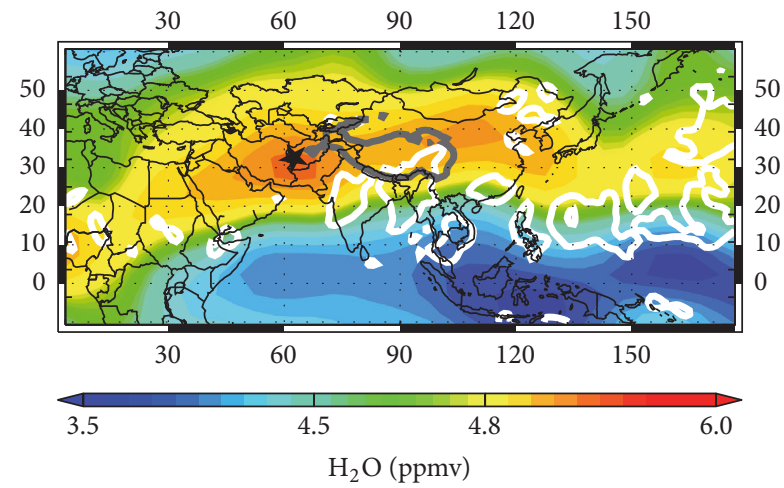

(d) $100 \mathrm{hPa}$ MLS $\mathrm{H}_{2} \mathrm{O}$ [ppmv] on Aug 9, 2016

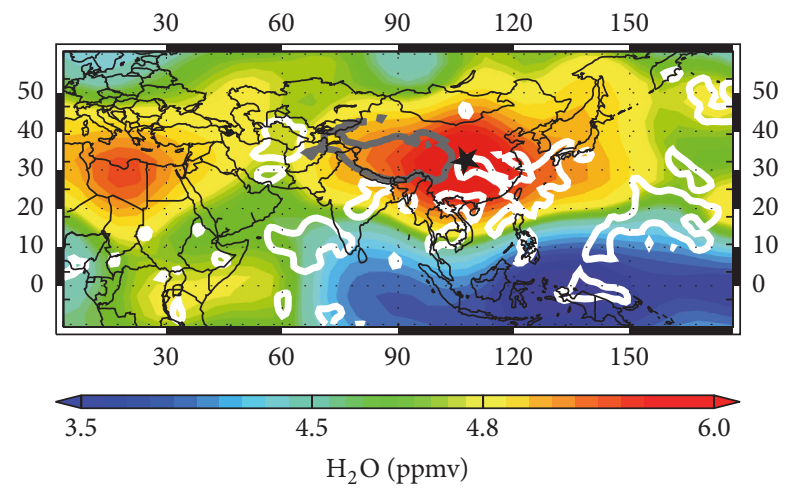

(f) $100 \mathrm{hPa}$ MLS $\mathrm{H}_{2} \mathrm{O}$ [ppmv] on Aug 14, 2016

FIgure 5: The same as Figure 3, but for $\mathrm{MLS}_{2} \mathrm{O}$ at $100 \mathrm{hPa}$.

The horizontal distribution of vertical velocity in the UTLS (see Figures 3-6) indicates that upward motion was mainly located to the southeast of TP. Figure 7 shows longitude-height cross-sections of vertical velocity along $20^{\circ} \mathrm{N}$. Regions within black contours represent where strong upward motion happened. Although the anticyclone was in the western mode on Aug 7 and Aug 9, and double centers phase occurred on Aug 10 and Aug 14, we can only found strong upward motion around $100 \mathrm{hPa}$ at $60^{\circ} \mathrm{E}$ (over Iranian Plateau) on Aug 7 during the period. The dynamical fields and $\mathrm{H}_{2} \mathrm{O}$ field all show that the anticyclone extended to the east of $150^{\circ} \mathrm{E}$ at $100 \mathrm{hPa}$ (Figure 1). Coincidentally, the persistent strong upward motion at $150^{\circ} \mathrm{E}$ in the period was found and they can reach $100 \mathrm{hPa}$.

The upward motion along $30^{\circ} \mathrm{N}$ was weaker than that along $20^{\circ} \mathrm{N}$ (Figure 8). But persistent upward motion still can be found at $150^{\circ} \mathrm{E}$ except on Aug 3. In addition, the upward motion in the UTLS was not consistent with the anticyclone migration. Strong upward transport on upper levels was always to the east of $60^{\circ} \mathrm{E}$.

In summary, upward motion was stronger along $30^{\circ} \mathrm{N}$ than along $20^{\circ} \mathrm{N}$. When the anticyclone migrated from Tibetan mode to Iranian mode, the upward motion in troposphere along both cross-sections did not change much. 


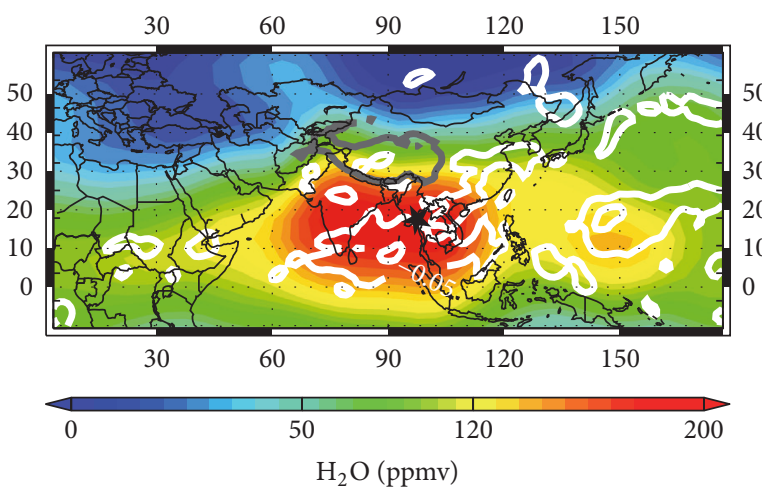

(a) $215 \mathrm{hPa}$ MLS $\mathrm{H}_{2} \mathrm{O}$ [ppmv] on Aug 3, 2016

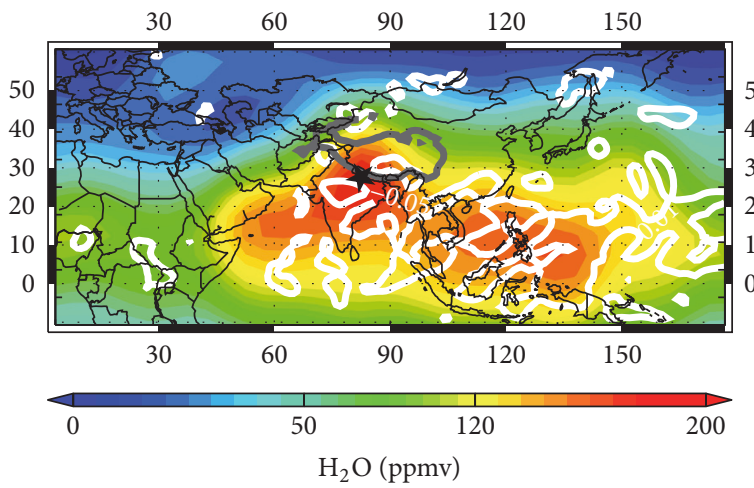

(c) $215 \mathrm{hPa}$ MLS $\mathrm{H}_{2} \mathrm{O}$ [ppmv] on Aug 7, 2016

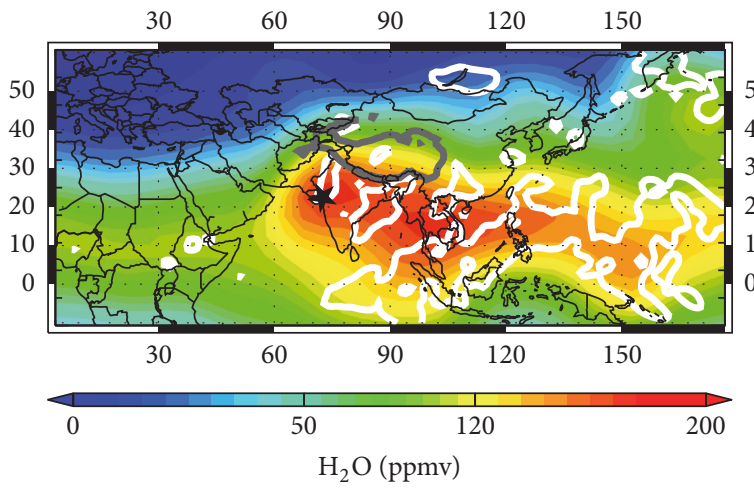

(e) $215 \mathrm{hPa}$ MLS $\mathrm{H}_{2} \mathrm{O}$ [ppmv] on Aug 10, 2016

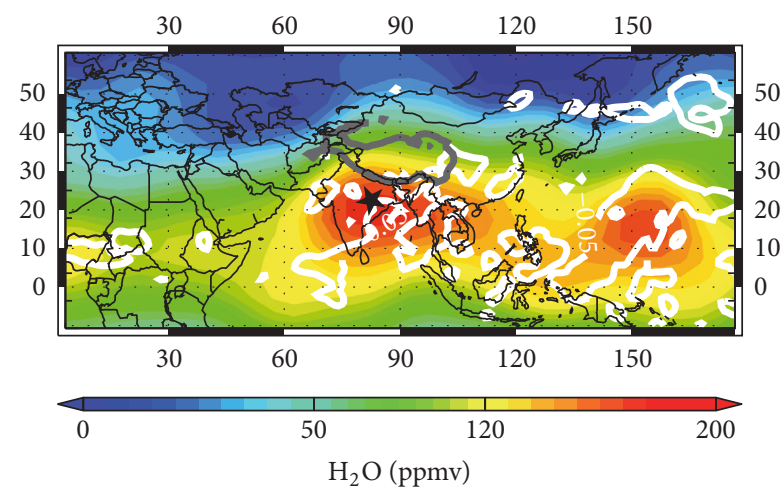

(b) $215 \mathrm{hPa}$ MLS $\mathrm{H}_{2} \mathrm{O}$ [ppmv] on Aug 5, 2016

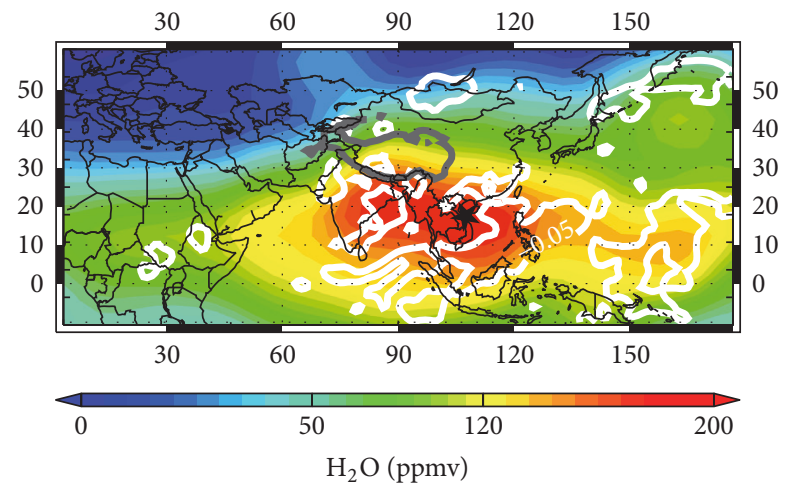

(d) $215 \mathrm{hPa}$ MLS $\mathrm{H}_{2} \mathrm{O}$ [ppmv] on Aug 9, 2016

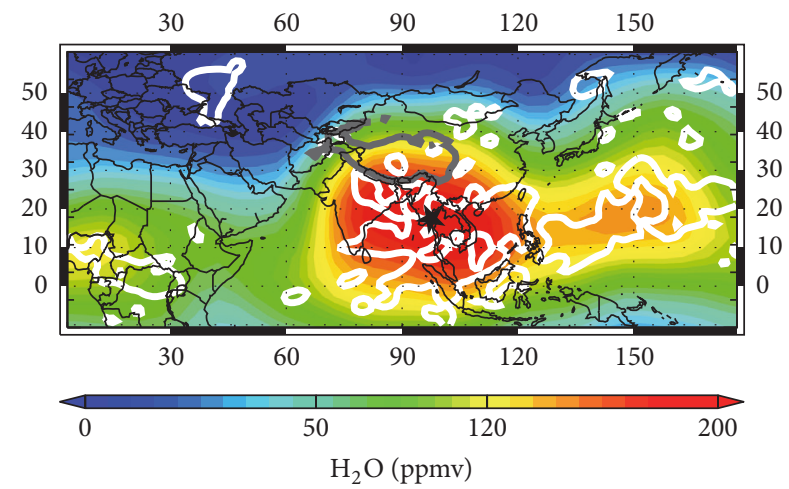

(f) $215 \mathrm{hPa} \mathrm{MLS} \mathrm{H}_{2} \mathrm{O}$ [ppmv] on Aug 14, 2016

Figure 6: The same as Figure 4, but for $\mathrm{MLS}_{2} \mathrm{O}$ at $215 \mathrm{hPa}$.

The strong upward transport in the UTLS was always to the east of $60^{\circ} \mathrm{E}$. There were also upward motions in the whole troposphere over Western Pacific. Thus, the relative high GPH center in the UTLS around $150^{\circ} \mathrm{E}$ (Figures 1 and 2) may be caused by both the eastward eddy shedding of the main anticyclone and tropospheric upward lifting.

\section{Trajectory Analysis}

Since the location of strong upward motion in the UTLS did not show east-west oscillation during the period we selected, we use HYSPLIT trajectory model to track how the air parcels transport when the anticyclone oscillated. $\mathrm{CO}$ and $\mathrm{H}_{2} \mathrm{O}$ daily maps at $100 \mathrm{hPa}$ and $215 \mathrm{hPa}$ have revealed that their distributions at $215 \mathrm{hPa}$ are likely resulting from upward transport in troposphere. In trajectory analysis, we chose air at $16.8 \mathrm{~km}$ to investigate the air transport associated with the westward oscillation of the anticyclone.

In the sequence we chosen, the anticyclone was in the Tibetan mode at the beginning and then migrated to Iranian mode. An independent relative high GPH center over Western Pacific resulting from the eastward eddy shedding of the Asian summer monsoon anticyclone was also found during the period (Figure 1). We focus on the air transport 


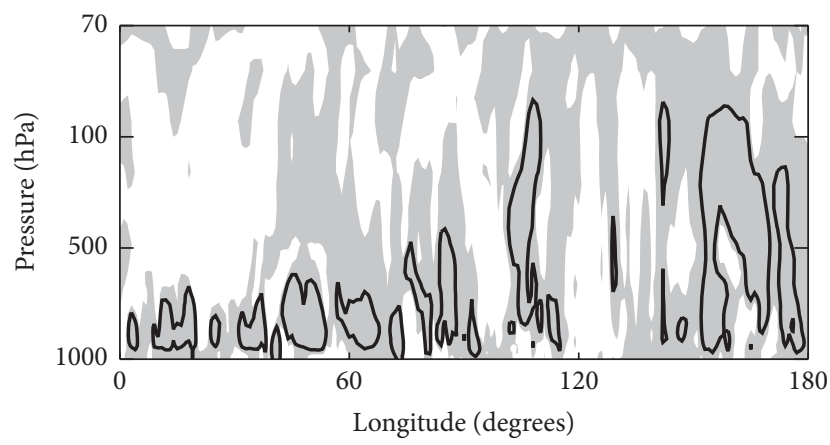

(a) Vertical velocity $[\mathrm{m} / \mathrm{s}]$ at $20^{\circ} \mathrm{N}$ on Aug 3, 2016

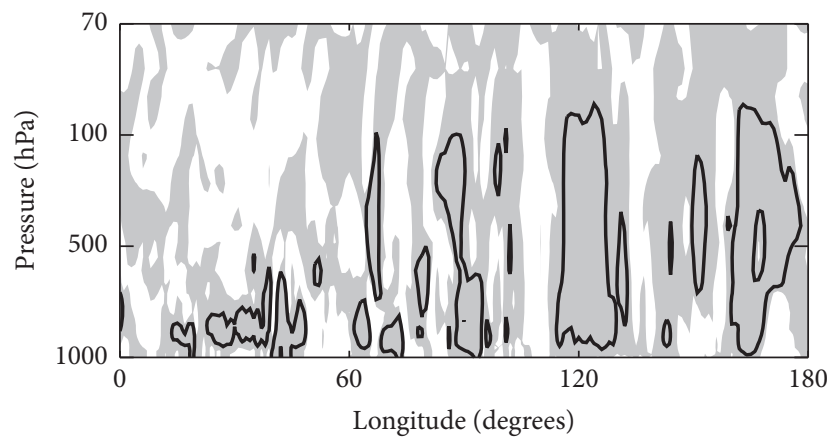

(c) Vertical velocity $[\mathrm{m} / \mathrm{s}]$ at $20^{\circ} \mathrm{N}$ on Aug 7, 2016

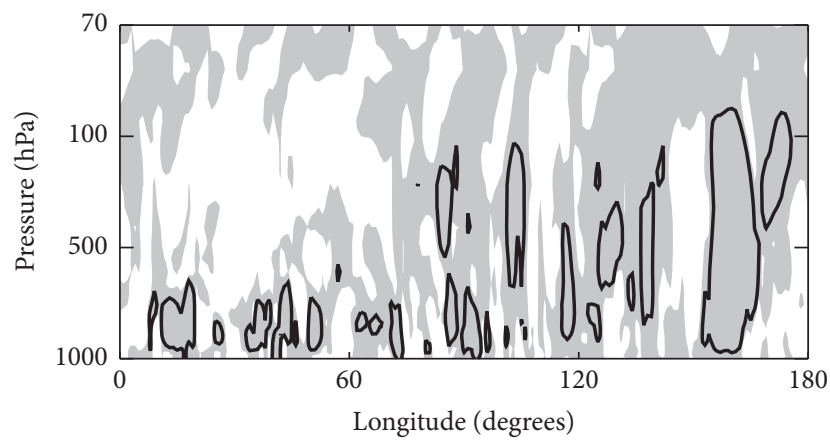

(e) Vertical velocity $[\mathrm{m} / \mathrm{s}]$ at $20^{\circ} \mathrm{N}$ on Aug 10, 2016

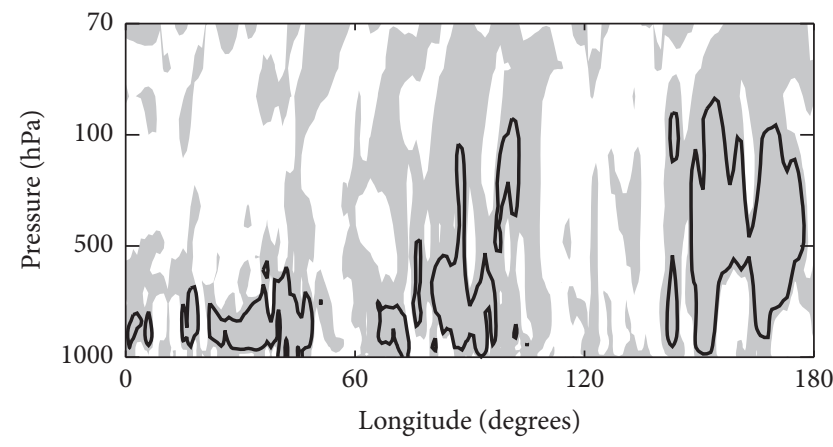

(b) Vertical velocity $[\mathrm{m} / \mathrm{s}]$ at $20^{\circ} \mathrm{N}$ on Aug 5, 2016

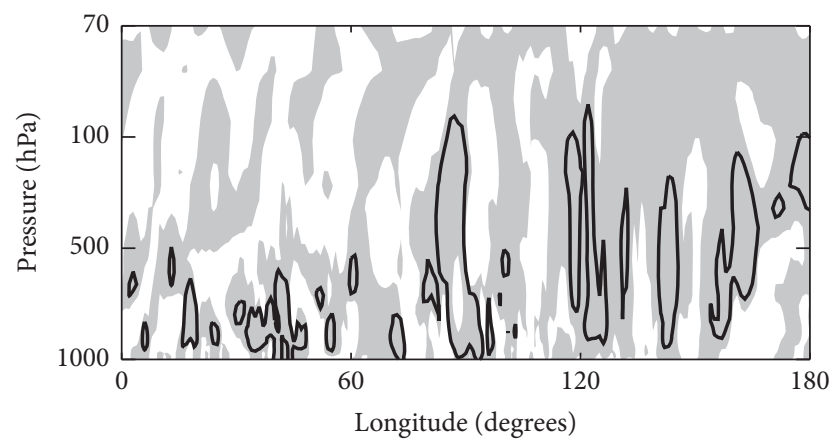

(d) Vertical velocity $[\mathrm{m} / \mathrm{s}]$ at $20^{\circ} \mathrm{N}$ on Aug 9, 2016

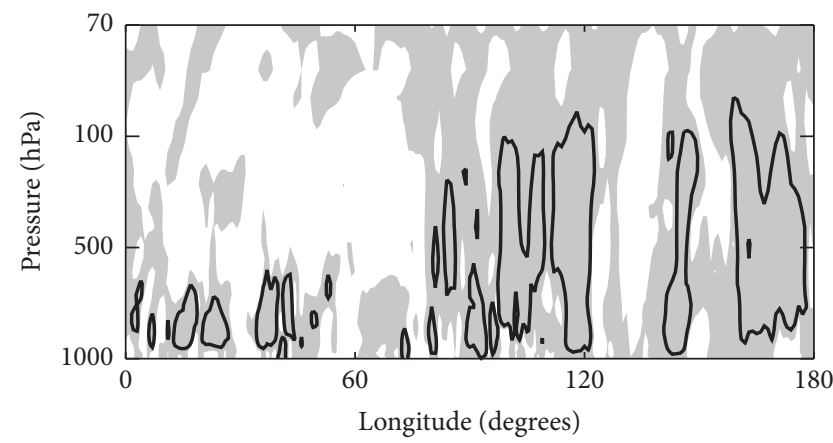

(f) Vertical velocity $[\mathrm{m} / \mathrm{s}]$ at $20^{\circ} \mathrm{N}$ on Aug 14,2016

Figure 7: A pressure-longitude cross section of vertical velocity along $20^{\circ} \mathrm{N}$ on (a) Aug 3, (b) Aug 5, (c) Aug 7, (d) Aug 9, (e) Aug 10, and (f) Aug 14, 2016. Gray shading regions indicate upward. Regions within black contours are strong upward motion regions (contour level is $-10 \mathrm{~Pa} / \mathrm{s})$.

when the anticyclone migrated from the Tibetan mode and the sources of the air within the anticyclone in the Iranian mode and over Western Pacific.

We first analyze the 5-day forward trajectories at $16.8 \mathrm{~km}$ released at $40^{\circ} \mathrm{N}, 100^{\circ} \mathrm{E}$ on Aug 3, 2016 (Figure 9). In the vertical direction, air parcels went both upward and downward. They can lower to $14 \mathrm{~km}$ and reach higher than $19 \mathrm{~km}$ after Aug 8 which meant the air within the anticyclone can transport across tropopause and into stratosphere. In general, the air parcels were maintained in the UTLS region in the 5 days. The horizontal pathway shows that air parcels went westward and eastward and remained around $100^{\circ} \mathrm{E}$. This is consistent with the fact that the anticyclone center moved from east to west and the eastward eddy shedding appeared from Aug 3 to Aug 9 (Figure 1).
As it is shown in Figures 7 and 8, strong upward motion in troposphere, especially on upper levels, was always to the east of $60^{\circ} \mathrm{E}$. However, the anticyclone located over IP on Aug 7 and Aug 9, 2016. It motivated us to analyze the backward trajectories of air within the anticyclone in the Iranian mode. Figure 10 is the 5-day ensemble backward trajectories at $16.8 \mathrm{~km}$ where the departure point is at $33^{\circ} \mathrm{N}, 60^{\circ} \mathrm{E}$ on Aug 9, 2016. It is shown that all the air parcels were from levels above $14 \mathrm{~km}$ and all came from the east. That is to say the air within the anticyclone over IP was entirely cause by westward migration of the anticyclone.

Differently, air within the relative high GPH center which located over Western Pacific has two sources (Figure 11). One part was from the main anticyclone over TP, while the other was from southern regions below. The vertical trajectories 


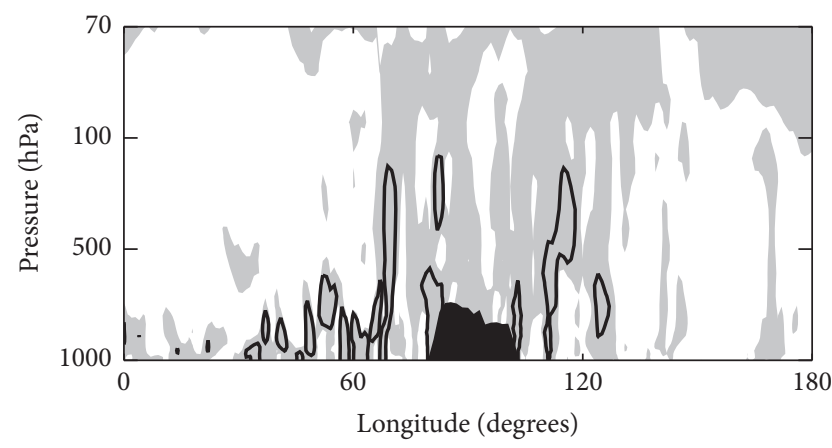

(a) Vertical velocity $[\mathrm{m} / \mathrm{s}]$ at $30^{\circ} \mathrm{N}$ on Aug 3, 2016

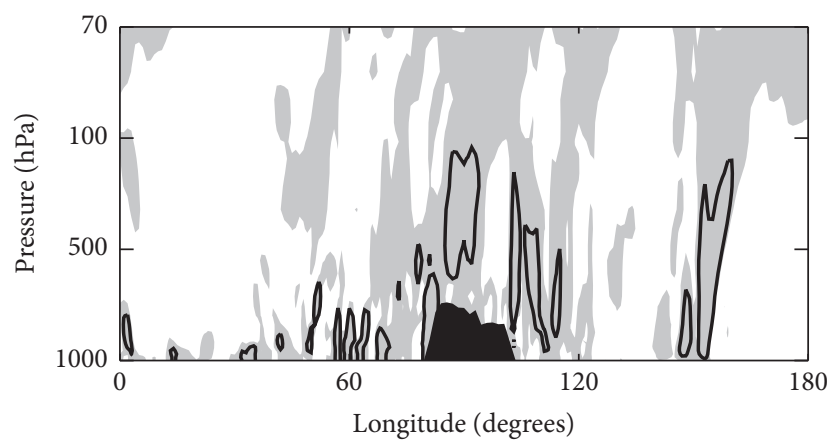

(c) Vertical velocity $[\mathrm{m} / \mathrm{s}]$ at $30^{\circ} \mathrm{N}$ on Aug 7, 2016

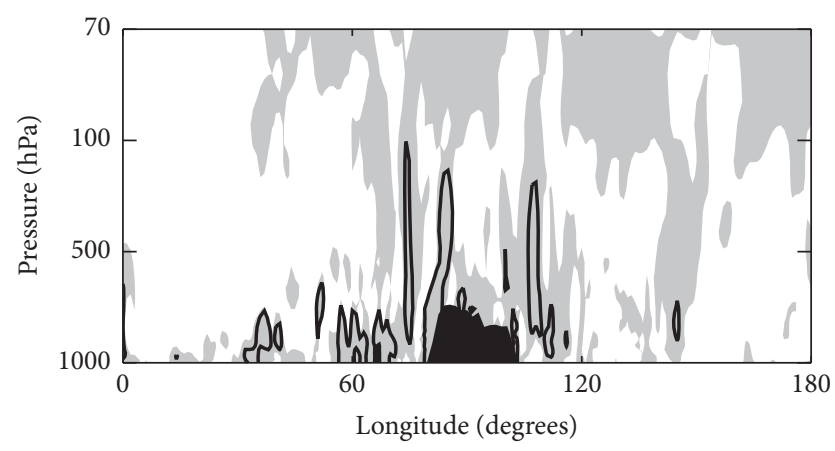

(e) Vertical velocity $[\mathrm{m} / \mathrm{s}]$ at $30^{\circ} \mathrm{N}$ on Aug 10, 2016

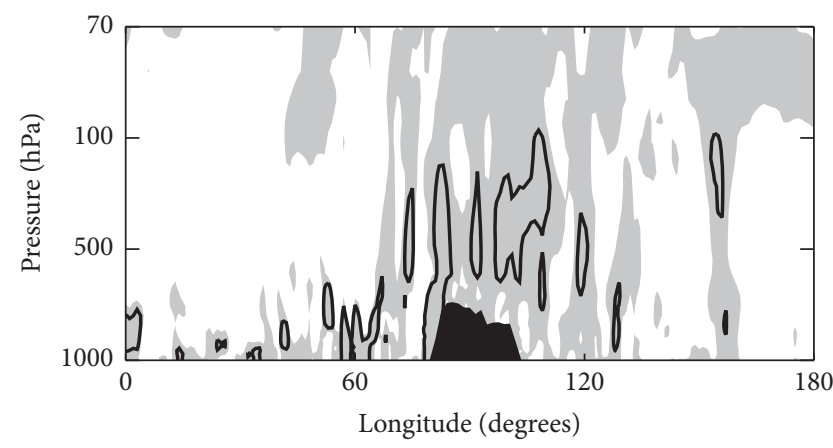

(b) Vertical velocity $[\mathrm{m} / \mathrm{s}]$ at $30^{\circ} \mathrm{N}$ on Aug 5, 2016

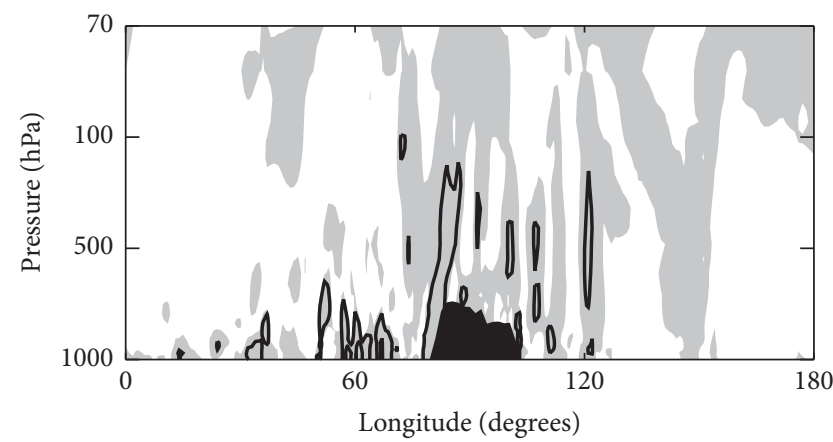

(d) Vertical velocity $[\mathrm{m} / \mathrm{s}]$ at $30^{\circ} \mathrm{N}$ on Aug 9, 2016

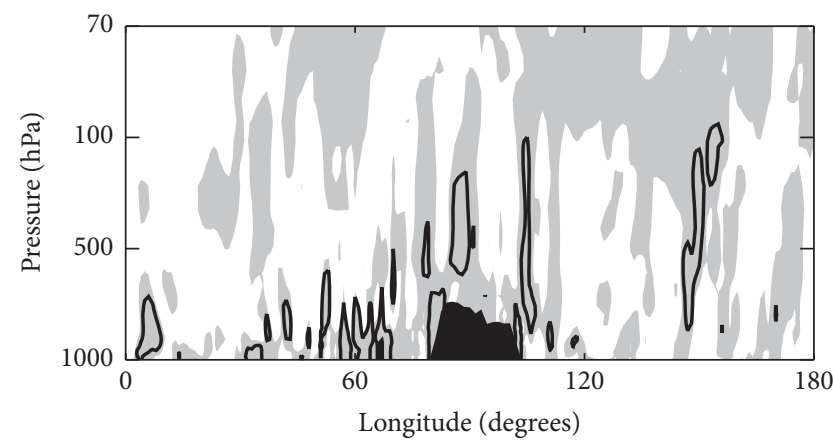

(f) Vertical velocity $[\mathrm{m} / \mathrm{s}]$ at $30^{\circ} \mathrm{N}$ on Aug 14, 2016

Figure 8: The same as Figure 7, but along $30^{\circ} \mathrm{N}$. Black shading indicates terrain.

show that all the air parcels here were from lower levels or same levels. Although the 5-day backward trajectories indicate that air was from levels above $10 \mathrm{~km}$, the analysis of vertical velocity above shows that there were persistent upward motions in the UTLS in this region (Figures 3-6) and in the whole troposphere at $30^{\circ} \mathrm{N}$.

Overall, the trajectory analysis illustrates that when the anticyclone migrated from east to west, air within the anticyclone was maintained in the UTLS, moved both westward and eastward, and may also stay over TP. All the air within the anticyclone in the Iranian mode was transported by the westward migration of the anticyclone, while air within the relative high GPH center over Western Pacific was from both eastward eddy shedding of the anticyclone and air on lower levels.

\section{Conclusions}

Using the 6-hourly EAR-Interim reanalysis data, MLS observations, and HYSPLIT trajectory model, we have studied CO and water vapor distributions and air transport in the UTLS associated with an east-west oscillation of Asian summer monsoon anticyclone process in August 2016.

Our analysis shows that the anticyclone defined by relative high GPH at both $100 \mathrm{hPa}$ and $200 \mathrm{hPa}$ migrated from Tibetan mode to Iranian mode during the period we selected. Meanwhile, the eastward eddy shedding of the main anticyclone contributed to independent relative high GPH centers over Western Pacific. The anticyclone at $200 \mathrm{hPa}$ located southerly compared to that at $100 \mathrm{hPa}$.

$\mathrm{CO}$ daily maps at $100 \mathrm{hPa}$ during the same period illustrate the enhanced $\mathrm{CO}$ mixing ratio located between 0 
NOAA HYSPLIT model

Forward trajectories starting at 0000 UTC 03 Aug 16 CDC1 Mmeteorological data

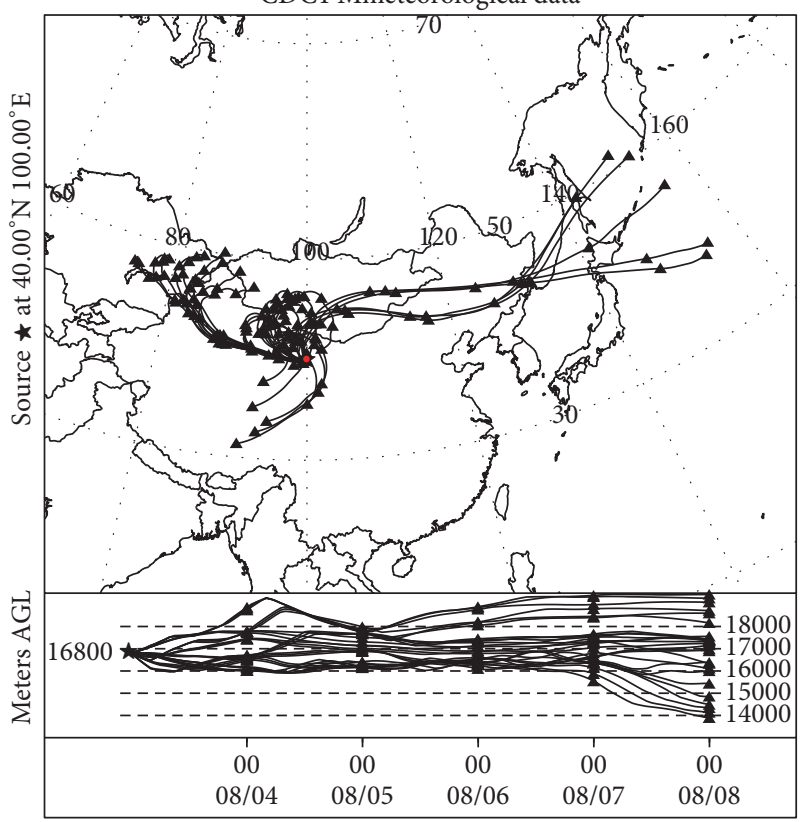

Figure 9: The ensemble forward trajectories at $16.8 \mathrm{~km}$ on Aug 3, 2016. The top part shows the time evolution of trajectories in the horizontal and the bottom part which indicates the vertical variation of trajectories with time. The trajectory released at $40^{\circ} \mathrm{N}, 100^{\circ} \mathrm{E}$ (red dot). The duration is 120 hours.

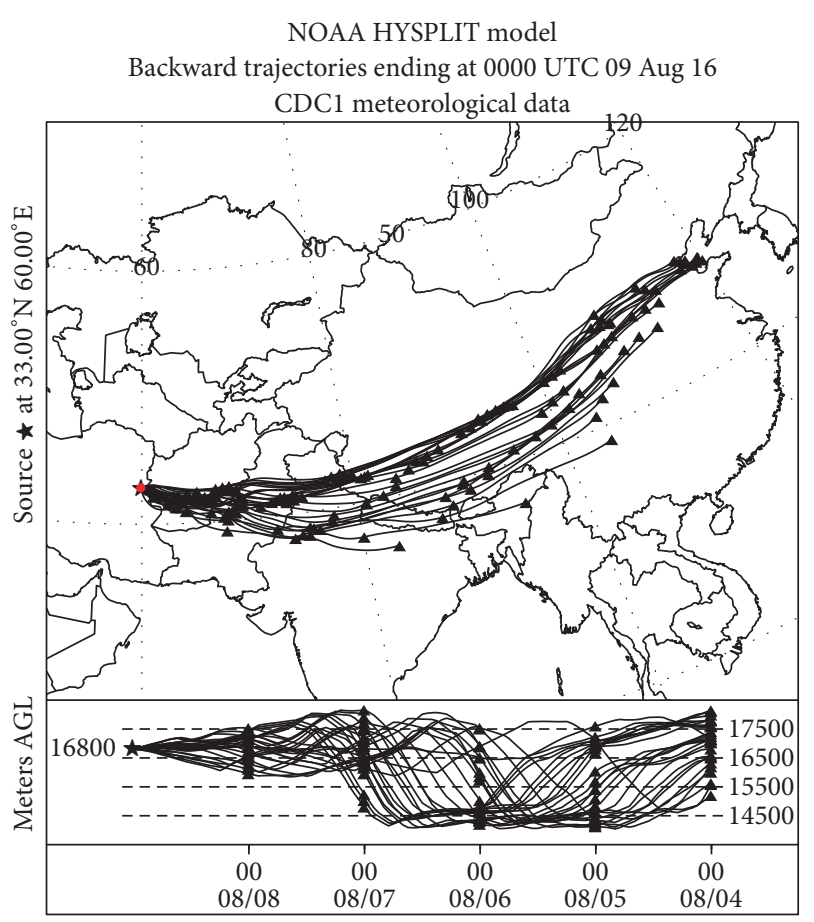

Figure 10: The ensemble backward trajectories at $16.8 \mathrm{~km}$ on Aug 9, 2016. The trajectory released at $33^{\circ} \mathrm{N}, 60^{\circ} \mathrm{E}$ (red dot). The duration is 120 hours.
NOAA HYSPLIT model

Backward trajectories ending at 0000 UTC 09 Aug 16 CDC1 meteorological data

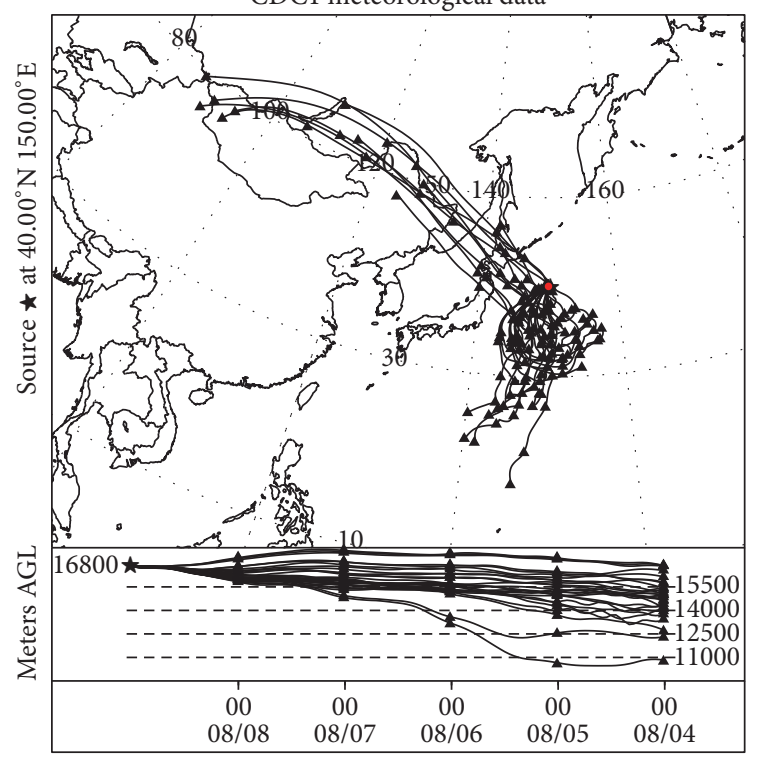

FIGURE 11: The ensemble backward trajectories at $16.8 \mathrm{~km}$ on Aug 9, 2016. The trajectory released at $40^{\circ} \mathrm{N}, 150^{\circ} \mathrm{E}$ (red dot). The duration is 120 hours.

and $40^{\circ} \mathrm{N}$, to the west of $150^{\circ} \mathrm{E}$. The horizontal distribution of relative high $\mathrm{H}_{2} \mathrm{O}$ mixing ratio at $100 \mathrm{hPa}$ shows better consistency with the location of the anticyclone than CO. Both tracers did not show apparent relationship between their maximum concentration centers and regions with strong upward motion on this level. However, their horizontal distributions were both influenced by upward transport at $215 \mathrm{hPa}$. Although the east-west migration of the anticyclone at $215 \mathrm{hPa}$ was still very clear, high values of both tracers were always to the east of $60^{\circ} \mathrm{E}$. Note that enhanced $\mathrm{H}_{2} \mathrm{O}$ mixing ratio was consistent with the eastward eddy shedding of the anticyclone on both levels but it was not evident in CO field.

The longitude-height cross-sections of vertical velocity along $20^{\circ} \mathrm{N}$ and $30^{\circ} \mathrm{N}$ indicate that persistent upward motion in troposphere was over TP and Western Pacific. But the upward motion was much stronger over $30^{\circ} \mathrm{N}$ than over $20^{\circ} \mathrm{N}$ and much weaker over IP.

The result from a trajectory model shows that when the anticyclone initiated in the Tibetan mode on Aug 3, the air within the anticyclone went both westward and eastward but was maintained in the UTLS in the following 5 days. Air within the anticyclone in the Iranian mode on Aug 9 was all from east in the UTLS which was caused by the east-west oscillation of the anticyclone. There was no upward transport from surface to tropopause over IP in this case. On the other hand, the eastward eddy shedding of the anticyclone only contributed to part of air within relative high GPH center over Western Pacific. The other part of the air was from levels below which was lifted by tropospheric upward motion.

Lastly, we want to emphasize that this study is a case study and based on MLS observations. To get a complete understanding of details in mass transport associated with the 
east-west oscillation of Asian summer monsoon, we should do more analysis.

\section{Conflicts of Interest}

The authors declare that they have no conflicts of interest.

\section{Acknowledgments}

Funding for this project was provided by the Science Foundations of China (41575038, 41405041, and 41605001).

\section{References}

[1] W. J. Randel and M. Park, "Deep convective influence on the Asian summer monsoon anticyclone and associated tracer variability observed with Atmospheric Infrared Sounder (AIRS)," Journal of Geophysical Research Atmospheres, vol. 111, no. D12, Article ID D12314, 2006.

[2] C. Normand, "Monsoon seasonal forecasting," Quarterly Journal of the Royal Meteorological Society, vol. 79, no. 342, pp. 463473, 1953.

[3] T. Yasunari, "The monsoon year-a new concept of the climatic year in the tropics," Bulletin of the American Meteorological Society, vol. 72, no. 9, pp. 1331-1338, 1991.

[4] P. J. Webster and S. Yang, "Monsoon and enso: selectively interactive systems," Quarterly Journal of the Royal Meteorological Society, vol. 118, no. 507, pp. 877-926, 1992.

[5] G. A. Meehl, "A coupled airsea biennial mechanism in the tropical indian and pacific regions: role of the ocean," Journal of Climate, vol. 6, pp. 31-41, 1993.

[6] G. A. Meehl, "Coupled land-ocean-atmosphere processes and South Asian monsoon variability," Science, vol. 266, no. 5183, pp. 263-267, 1994.

[7] J. Yang, Q. Liu, S. Xie, Z. Liu, and L. Wu, "Impact of the Indian Ocean SST basin mode on the Asian summer monsoon," Geophysical Research Letters, vol. 34, no. 2, 2007.

[8] T. J. Dunkerton, "Evidence of meridional motion in the summer lower stratosphere adjacent to monsoon regions," Journal of Geophysical Research, vol. 100, no. 8, pp. 675-688, 1995.

[9] A. Dethof, A. O’Neill, J. M. Slingo, and H. G. J. Smit, “A mechanism for moistening the lower stratosphere involving the Asian summer monsoon," Quarterly Journal of the Royal Meteorological Society, vol. 125, no. 556, pp. 1079-1106, 1999.

[10] B. Chen, X. D. Xu, S. Yang, and T. L. Zhao, "Climatological perspectives of air transport from atmospheric boundary layer to tropopause layer over Asian monsoon regions during boreal summer inferred from Lagrangian approach," Atmospheric Chemistry and Physics, vol. 12, no. 13, pp. 5827-5839, 2012.

[11] Y. Ding, "Summer monsoon rainfalls in China," Journal of the Meteorological Society of Japan, vol. 70, no. 1B, pp. 397-421, 1992.

[12] F. W. Zwiers, "Simulation of the Asian summer monsoon with the CCC GCM-1," Journal of Climate, vol. 6, no. 3, pp. 470-486, 1993.

[13] H. Annamalai, J. M. Slingo, K. R. Sperber, and K. Hodges, “The mean evolution and variability of the asian summer monsoon: comparison of ECMWF and NCEP-NCAR reanalyses," Monthly Weather Review, vol. 127, no. 6, pp. 1157-1186, 1999.

[14] B. Wang and Z. Fan, "Choice of south asian summer monsoon indices," Bulletin of the American Meteorological Society, vol. 80, no. 4, pp. 629-638, 1999.
[15] K.-M. Lau, K.-M. Kim, and S. Yang, "Dynamical and boundary forcing characteristics of regional components of the Asian summer monsoon," Journal of Climate, vol. 13, no. 14, pp. 2461$2482,2000$.

[16] S. Chun-Hua, L. Hui, Z. Bin, G. Dong, and L. Ren-Qiang, "Stratosphere-troposphere exchange corresponding to a deep convection in the warm sector and abnormal subtropical front induced by a cutoff low over east asia," Chinese Journal of Geophysics, vol. 57, no. 1, pp. 21-30, 2014 (Chinese).

[17] C. H. Shi, B. Zheng, Y. J. Chen, and Y. Bi, “The quasi-biennial oscillation of water vapor in tropic stratosphere," Chinese Journal of Geophysics, vol. 52, no. 10, pp. 2428-2435, 2009 (Chinese).

[18] K. H. Rosenlof, A. F. Tuck, K. K. Kelly, J. M. R. Lii, and M. P. McCormick, "Hemispheric asymmetries in water vapor and inferences about transport in the lower stratosphere," Journal of Geophysical Research: Atmospheres, vol. 102, no. D11, pp. 1321313234, 1997.

[19] R. N. Bannister, A. O’Neill, A. R. Gregory, and K. M. Nissen, "The role of the south-east Asian monsoon and other seasonal features in creating the 'tape-recorder' signal in the Unified Model," Quarterly Journal of the Royal Meteorological Society, vol. 130, no. 599, pp. 1531-1554, 2004.

[20] A. Gettelman, D. E. Kinnison, T. J. Dunkerton, and G. P. Brasseur, "Impact of monsoon circulations on the upper troposphere and lower stratosphere," Journal of Geophysical Research D: Atmospheres, vol. 109, no. 22, pp. 51-67, 2004.

[21] Q. Li, J. H. Jiang, D. L. Wu et al., "Convective outflow of south asian pollution: a global CTM simulation compared with EOS MLS observations," Geophysical Research Letters, vol. 32, no. 14, pp. 1-4, 2005.

[22] R. Fu, Y. Hu, J. S. Wright et al., "Short circuit of water vapor and polluted air to the global stratosphere by convective transport over the Tibetan Plateau," Proceedings of the National Academy of Sciences of the United States of America, vol. 103, no. 15, pp. 5664-5669, 2006.

[23] M. Park, W. J. Randel, A. Gettelman, S. T. Massie, and J. H. Jiang, "Transport above the Asian summer monsoon anticyclone inferred from Aura Microwave Limb Sounder tracers," Journal of Geophysical Research Atmospheres, vol. 112, no. 16, Article ID D16309, 2007.

[24] M. Park, W. J. Randel, L. K. Emmons, P. F. Bernath, K. A. Walker, and C. D. Boone, "Chemical isolation in the Asian monsoon anticyclone observed in Atmospheric Chemistry Experiment (ACE-FTS) data," Atmospheric Chemistry and Physics, vol. 8, no. 3, pp. 757-764, 2008.

[25] M. Park, W. J. Randel, L. K. Emmons, and N. J. Livesey, "Transport pathways of carbon monoxide in the Asian summer monsoon diagnosed from Model of Ozone and Related Tracers (MOZART)," Journal of Geophysical Research Atmospheres, vol. 114, no. 8, Article ID D08303, 2009.

[26] B. Chen, X.-D. Xu, S. Yang, and W. Zhang, "On the temporal and spatial structure of troposphere-to-stratosphere transport in the lowermost stratosphere over the Asian monsoon region during boreal summer," Advances in Atmospheric Sciences, vol. 29, no. 6, pp. 1305-1317, 2012.

[27] D. Guo, Y. Su, X. Zhou et al., "Evaluation of the trend uncertainty in summer ozone valley over the Tibetan Plateau in three reanalysis datasets," Journal of Meteorological Research, vol. 31, no. 2, pp. 431-437, 2017. 
[28] D. Guo, Y. Su, C. Shi, J. Xu, and A. M. Powell, "Double core of ozone valley over the Tibetan Plateau and its possible mechanisms," Journal of Atmospheric and Solar-Terrestrial Physics, vol. 130, no. 8, pp. 127-131, 2015.

[29] D. Guo, P. Wang, X. Zhou, Y. Liu, and W. Li, "Dynamic effects of the South Asian high on the ozone valley over the Tibetan Plateau," Acta Meteorologica Sinica, vol. 26, no. 2, pp. 216-228, 2012.

[30] M. Park, W. J. Randel, D. E. Kinnison, R. R. Garcia, and W. Choi, "Seasonal variation of methane, water vapor, and nitrogen oxides near the tropopause: satellite observations and model simulations," Journal of Geophysical Research: Atmospheres, vol. 109, no. D3, 2004.

[31] W. J. Randel, M. Park, L. Emmons et al., "Asian monsoon transport of pollution to the stratosphere," Science, vol. 328, no. 5978, pp. 611-613, 2010.

[32] D. R. Jackson, S. J. Driscoll, E. J. Highwood, J. E. Harries, and J. M. Russell, "Troposphere to stratosphere transport at low latitudes as studied using HALOE observations of water vapour 1992-1997," Quarterly Journal of the Royal Meteorological Society, vol. 124, no. 545, pp. 169-192, 1998.

[33] J.-P. Vernier, L. W. Thomason, and J. Kar, "CALIPSO detection of an Asian tropopause aerosol layer," Geophysical Research Letters, vol. 38, no. 7, Article ID L07804, 2011.

[34] H. Garny and W. J. Randel, "Dynamic variability of the Asian monsoon anticyclone observed in potential vorticity and correlations with tracer distributions," Journal of Geophysical Research Atmospheres, vol. 118, no. 24, pp. 13421-13433, 2013.

[35] C. Juno Hsu and R. Alan Plumb, "Nonaxisymmetric thermally driven circulations and upper-tropospheric monsoon dynamics," Journal of the Atmospheric Sciences, vol. 57, no. 9, pp. 12551276, 2000.

[36] J. M. Popovic and R. A. Plumb, "Eddy shedding from the upper-tropospheric Asian monsoon anticyclone," Journal of the Atmospheric Sciences, vol. 58, no. 1, pp. 93-104, 2001.

[37] Q. Zhang, G. Wu, and Y. Qian, “The bimodality of the $100 \mathrm{hPa}$ South Asia High and its relationship to the climate anomaly over East Asia in summer," Journal of the Meteorological Society of Japan, vol. 80, no. 4, pp. 733-744, 2002.

[38] Y. Ren-Chang, B. Jian-Chun, and F. Qiu-Jun, "The impact of the south asia high bimodality on the chemical composition of the upper troposphere and lower stratosphere," Atmospheric and Oceanic Science Letters, vol. 4, no. 4, pp. 229-234, 2011.

[39] L. L. Pan, S. B. Honomichl, D. E. Kinnison et al., "Transport of chemical tracers from the boundary layer to stratosphere associated with the dynamics of the Asian summer monsoon," Journal of Geophysical Research: Atmospheres, vol. 121, no. 23, pp. 14-174, 2016.

[40] J. W. Bergman, F. Fierli, E. J. Jensen, S. Honomichl, and L. L. Pan, "Boundary layer sources for the asian anticyclone: regional contributions to a vertical conduit," Journal of Geophysical Research D: Atmospheres, vol. 118, no. 6, pp. 2560-2575, 2013.

[41] N. K. Heath and H. E. Fuelberg, "Using a WRF simulation to examine regions where convection impacts the Asian summer monsoon anticyclone," Atmospheric Chemistry and Physics, vol. 14, no. 4, pp. 2055-2070, 2014.

[42] H. Garny and W. J. Randel, "Transport pathways from the Asian monsoon anticyclone to the stratosphere," Atmospheric Chemistry and Physics Discussions, vol. 15, no. 18, pp. 2598126023, 2015.
[43] K. P. Bowman, "Transport of carbon monoxide from the tropics to the extratropics," Journal of Geophysical Research Atmospheres, vol. 111, no. 2, Article ID D02107, pp. 109-125, 2006.

[44] Y. Xiao, D. J. Jacob, and S. Turquety, "Atmospheric acetylene and its relationship with $\mathrm{CO}$ as an indicator of air mass age," Journal of Geophysical Research Atmospheres, vol. 112, no. 12, Article ID D12305, 2007.

[45] J. Bian, L. L. Pan, L. Paulik, H. Vmel, H. Chen, and D. Lu, "In situ water vapor and ozone measurements in Lhasa and Kunming during the Asian summer monsoon," Geophysical Research Letters, vol. 39, no. 19, Article ID L19808, 2012.

[46] J. W. Waters, L. Froidevaux, R. S. Harwood et al., “The Earth Observing System Microwave Limb Sounder (EOS MLS) on the aura satellite," IEEE Transactions on Geoscience and Remote Sensing, vol. 44, no. 5, pp. 1075-1092, 2006.

[47] N. J. Livesey, W. G. Read, P. A. Wagner et al., "Version 4.2 level 2 data quality and description document," 2015.

[48] R. Draxler and G. D. Hess, "Description of the HYSPLIT_4 modeling system," NOAA Tech. Memo. ERL ARL-224, 1997.

[49] A. F. Stein, R. R. Draxler, G. D. Rolph, B. J. B. Stunder, M. D. Cohen, and F. Ngan, "Noaa's hysplit atmospheric transport and dispersion modeling system," Bulletin of the American Meteorological Society, vol. 96, no. 12, pp. 2059-2077, 2015.

[50] G. Rolph, A. Stein, and B. Stunder, "Real-time environmental applications and display system: ready," Environmental Modelling \& Software, vol. 95, pp. 210-228, 2017.

[51] R. R. Draxler, "The use of global and mesoscale meteorological model data to predict the transport and dispersion of tracer plumes over Washington, D.C," Weather and Forecasting, vol. 21, no. 3, pp. 383-394, 2006.

[52] J. Luo, W. Tian, Z. Pu et al., "Characteristics of stratospheretroposphere exchange during the Meiyu season," Journal of Geophysical Research Atmospheres, vol. 118, no. 4, pp. 20582072, 2013.

[53] R. Draxler, B. Stunder, G. Rolph, A. Stein, and A. Taylor, "HYSPLIT4 user's guide," 2012, http://www.arl.noaa.gov/documents/reports/hysplit_user_guide.pdf.

[54] W. J. Randel, F. Wu, A. Gettelman, J. M. Russell III, J. M. Zawodny, and S. J. Oltmans, "Seasonal variation of water vapor in the lower stratosphere observed in Halogen Occultation Experiment data," Journal of Geophysical Research Atmospheres, vol. 106, no. 13, Article ID 2001JD900048, pp. 14313-14325, 2001. 

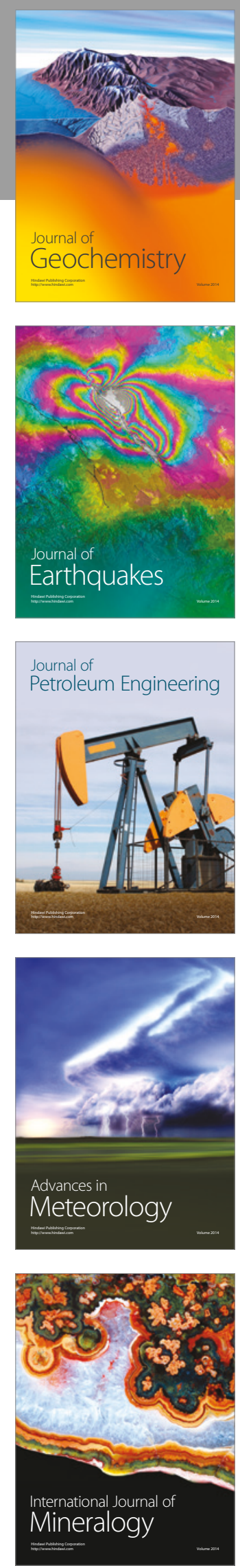
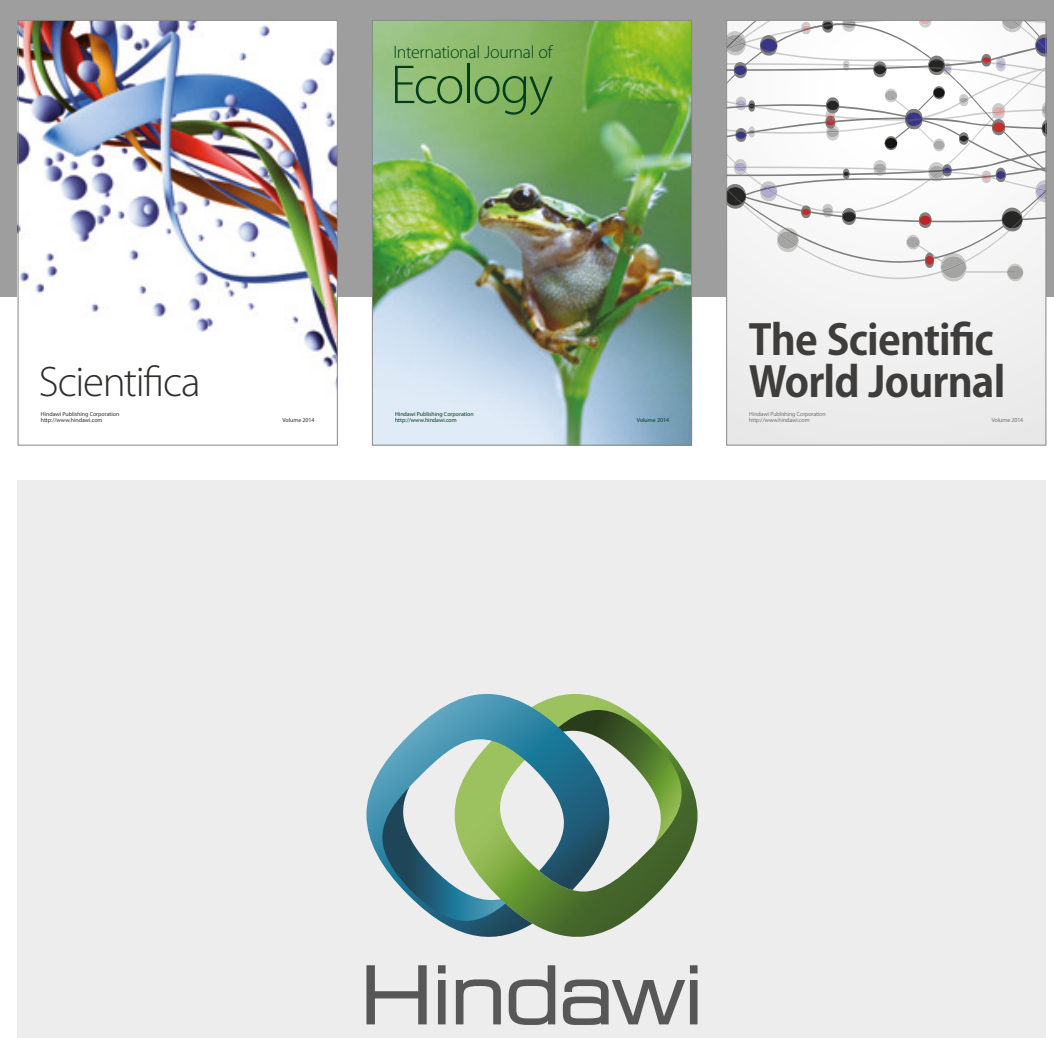

Submit your manuscripts at

https://www.hindawi.com
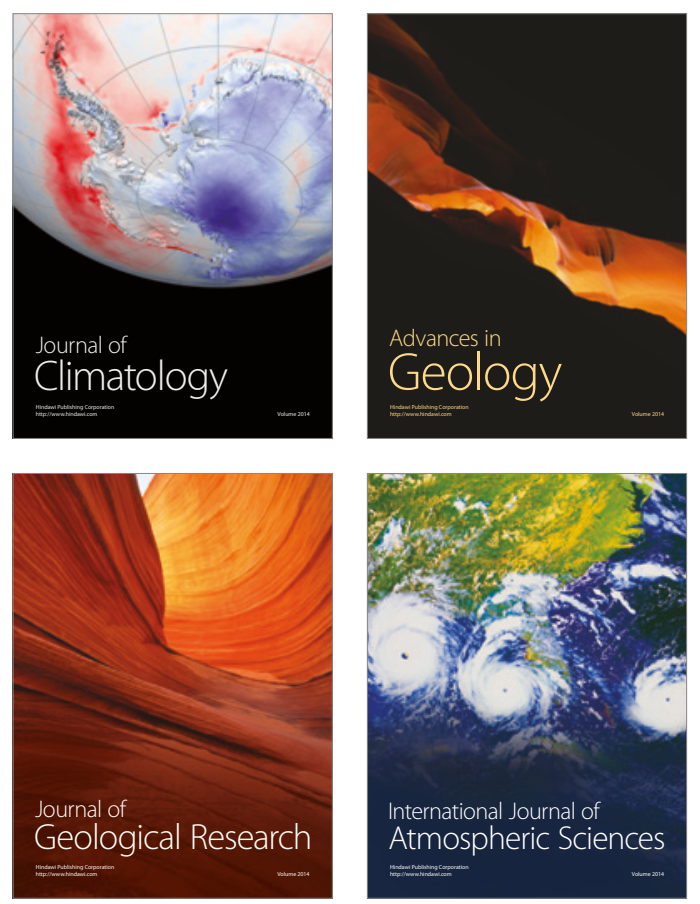

The Scientific

World Journal
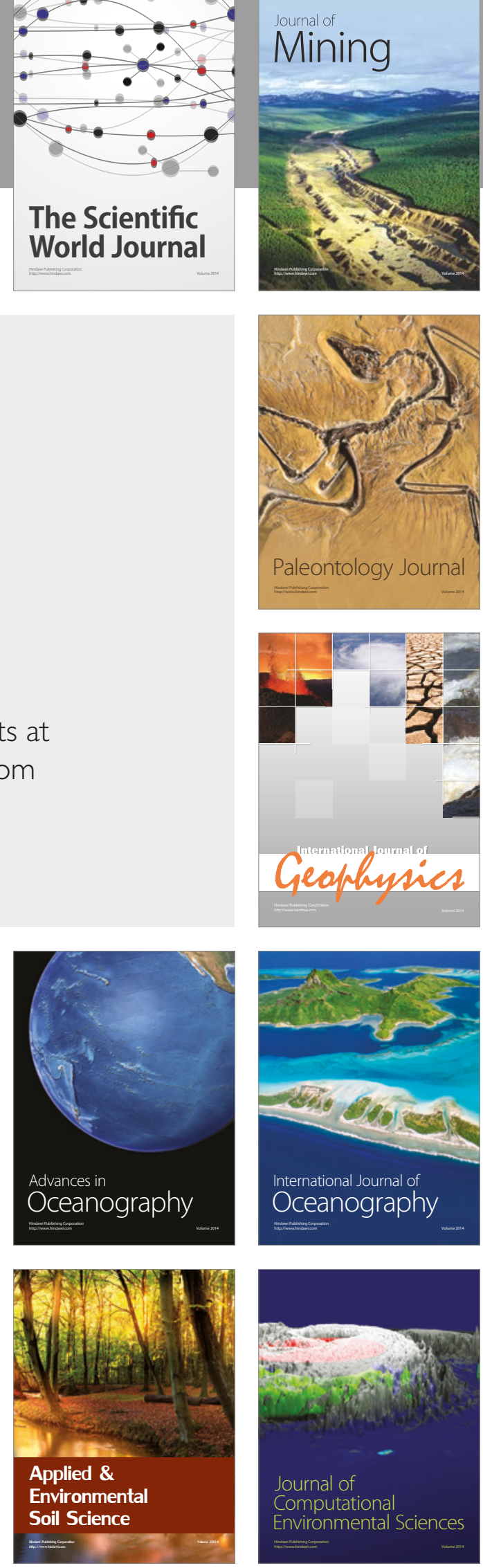